FEDERAL

RESERVE

BANK of

ST. LOUIS
RESEARCH DIVISION

Working Paper Series

\title{
Housing Prices and the High Chinese Saving Rate Puzzle
}

\author{
Xin Wang \\ and \\ Yi Wen
}

\author{
Working Paper 2012-038A \\ https://doi.org/10.20955/wp.2012.038
}

September 2012

\section{FEDERAL RESERVE BANK OF ST. LOUIS}

Research Division

P.O. Box 442

St. Louis, MO 63166

The views expressed are those of the individual authors and do not necessarily reflect official positions of the Federal Reserve Bank of St. Louis, the Federal Reserve System, or the Board of Governors.

Federal Reserve Bank of St. Louis Working Papers are preliminary materials circulated to stimulate discussion and critical comment. References in publications to Federal Reserve Bank of St. Louis Working Papers (other than an acknowledgment that the writer has had access to unpublished material) should be cleared with the author or authors. 


\title{
Housing Prices and the High Chinese Saving Rate Puzzle*
}

\author{
Xin Wang \\ Tsinghua University \\ Yi Wen \\ Federal Reserve Bank of St. Louis \\ \& Tsinghua University
}

\begin{abstract}
China's over 25\% aggregate household saving rate is one of the highest in the world. One popular view attributes the high saving rate to fast-rising housing prices in China. However, cross-sectional data do not show a significant relationship between housing prices and household saving rates. This article uses a simple consumption-saving model to explain why rising housing prices per se cannot explain China's high household saving rate. Although borrowing constraints and demographic changes can translate housing prices to the aggregate saving rate, quantitative simulations of our model using Chinese time-series data on household income, housing prices, and demographics indicate that rising mortgage costs can increase the aggregate saving rate by at most 2 to 4 percentage points in the best down-payment structure.
\end{abstract}

Keywords: Chinese Economy, Housing, Saving Rate, Borrowing Constraints, Housing Reform.

JEL Codes: D14, D91, E21, I31, R21

\footnotetext{
* A shorter version of this paper appeared in the Federal Reserve Bank of St. Louis Review, March/April 2011, 93(2) 67-88. We thank Jiandong Ju, Yue Liu, Qing Liu, Xue Qiao, Xinzheng Shi, Michael Zheng Song, Xiaoxia Wang, Ziru Wei, Binzhen Wu, Weilong Zhang, Xiaohan Zhong, and two anonymous referees for helpful comments, Zhenjie Qian for sharing data and Judy Ahlers for editorial assistance.
} 


\section{Introduction}

According to Friedman's (1957) permanent income hypothesis, rational consumers should save less when their income is growing faster because the need to save is reduced when people expect to be richer in the future than they are today. However, the reality in China is the opposite: As one of the fastest-growing economies, China's aggregate household saving rate is among the highest in the world.

Housing investment is commonly included in the measured household saving rate. Thus, if shelter is more or less a necessary consumption good (e.g., due to the lack of a well-developed rental market), then rising housing prices could potentially explain the high aggregate household saving rate in China. However, even excluding housing investment, China's aggregate saving rate is still one of the highest in the world.

To understand whether rising housing prices can contribute to such a high aggregate household saving rate, we define the "aggregate household saving rate" in this paper as the ratio of net changes in aggregate household financial wealth (e.g., bank deposits, government bonds, and stocks) to aggregate household disposable income. ${ }^{1}$ We adopt this definition also for several other reasons:

(i) If housing investment is included in the saving rate, then using rising housing prices to explain the level of rising housing expenditures (housing investment) is more or less tautological and thus uninteresting.

(ii) Because shelters are durable goods, the purchase of a home immediately reduces the need of future expenditures on rental payments, thus increasing future savings. Therefore, including housing investment in the household saving rate implies double counting of a person's average lifetime saving rate because the market value of a house is related to the present value of discounted future rental expenditures. Since housing investment is financed by financial wealth (such as bank deposits) or bank loans, the reduction in financial wealth or the increase in bank loans to finance

\footnotetext{
${ }^{1}$ Bank deposits account for the bulk of household financial wealth in China.
} 
housing purchases can thus be treated as negative saving to society. Thus, our definition is consistent with that adopted by Hayashi (1986), who converts housing investment (expenditures) into future rents and treats these rents as consumption.

(iii) China's high saving rate has been considered as one of the most important causes of China's trade imbalances with the rest of the world. Since houses are nontradable goods, including housing investment in the saving rate does not change the difference between the aggregate saving rate and national investment rate (i.e., net exports) and thus is not helpful in understanding China's trade imbalances.

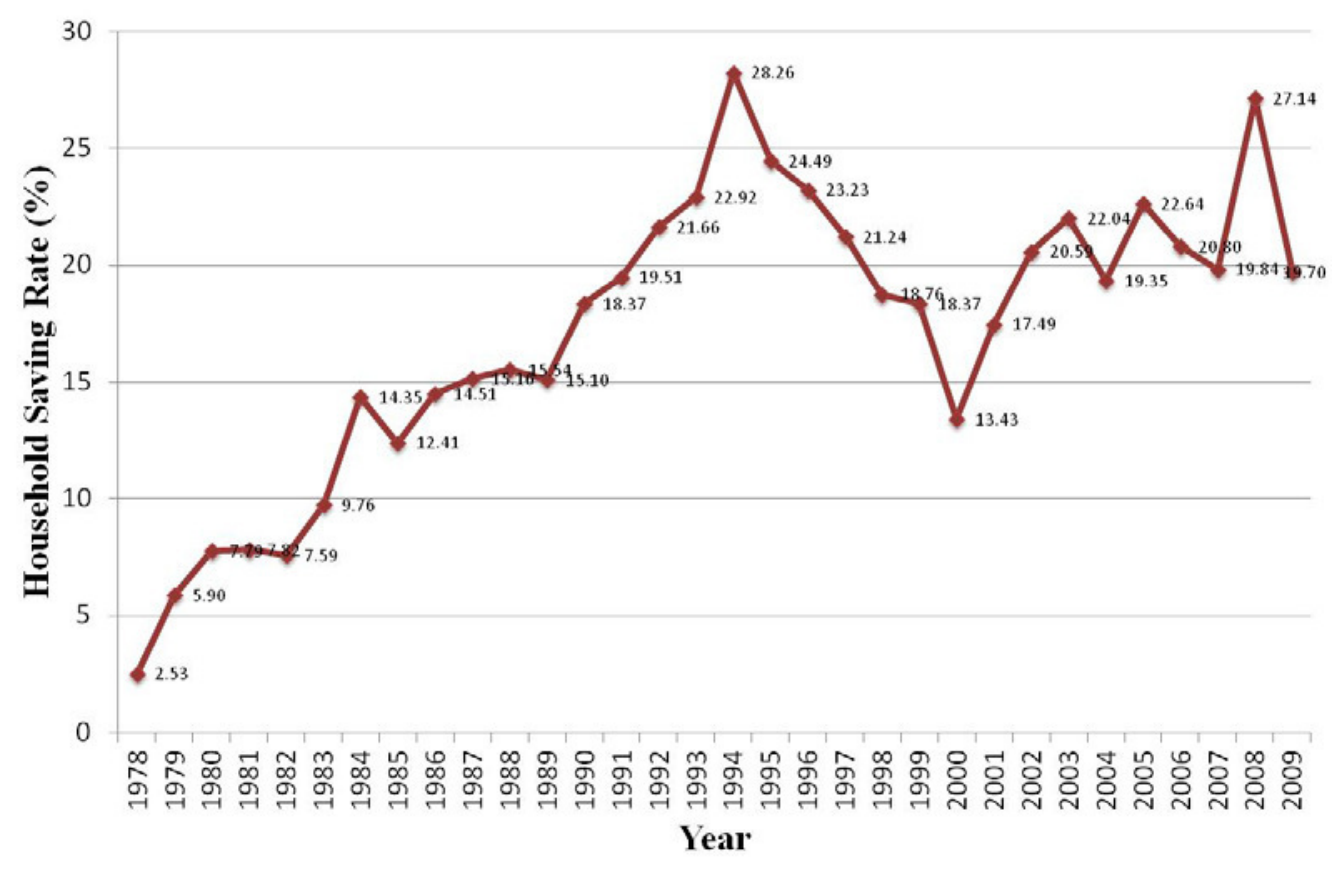

Figure 1. Chinese Household Saving Rate (1978-2009).

Figure 1 shows the (redefined) aggregate household saving rate in China since 1978 (the starting year of economic reform). ${ }^{2}$ The saving rate was around $2.5 \%$ in 1978 but rose rapidly thereafter. It stabilized around $20 \%$ to $25 \%$ after the early 1990 s and peaked in 1994 and 2008 with values of $28 \%$ and 27\%, respectively.

Such a persistently high aggregate household saving rate is extraordinary compared with developed countries such as the United States, which has had an average household saving rate of $2 \%$ since the early 1990s. However, the high

\footnotetext{
${ }^{2}$ See the Appendix for detailed descriptions of data source and definitions.
} 
Chinese saving rate is not unique. Figure 2 shows the household saving rates for Japan and South Korea for the postwar period. Both economies had a high household saving rate—above 20 percent—during their rapid economic growth periods (Japan in the mid-1970s and Korea from 1987 to 1994). ${ }^{3}$

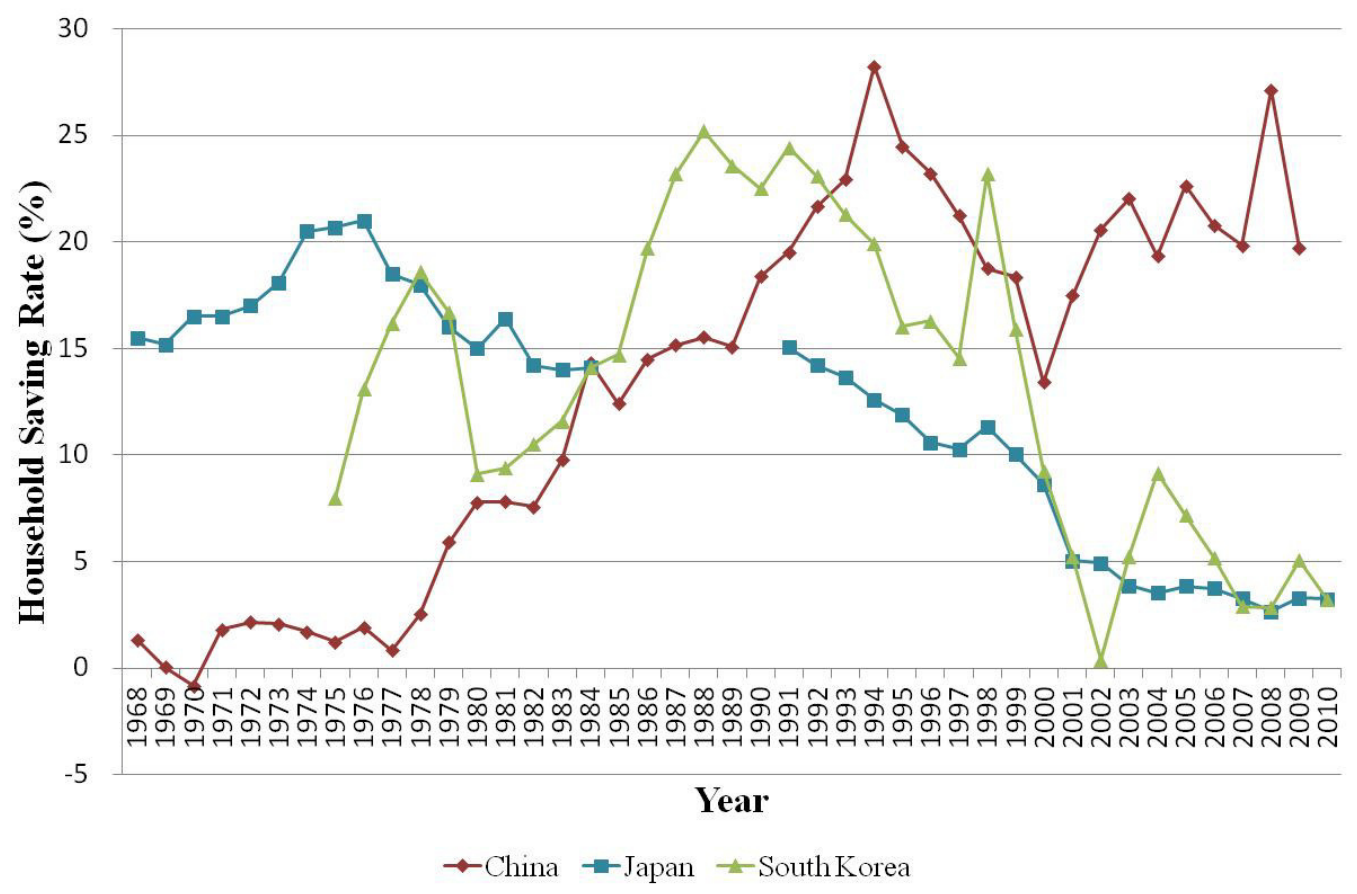

Figure 2. Cross-Country Comparison of Household Saving Rates (1968-2010).

Why the Japanese saved so much during its rapid economic development is still an open question (see, e.g., Hayashi, 1986). Hence, it is not surprising that the high Chinese saving rate appears puzzling, especially given China's persistently high income growth.

The high saving rate of Chinese households not only poses a challenge to economic theory, but also has become a source of recent political controversy and trade disputes with the United States and China's other major trading partners. For example, the former chairman of the Federal Reserve, Alan Greenspan, alleged that the high Chinese saving rate was likely the culprit of the recent American subprime mortgage crisis because it caused low interest rates in the world financial markets,

\footnotetext{
3 These data are based on the Organisation for Economic Co-operation and Development database, Hayashi (1986), and Bai and Qian (2009).
} 
which pushed Americans toward excessive consumption and housing finance. ${ }^{4}$ Current Chairman Ben Bernanke (2005) also argued that the "global saving glut" is partly responsible for the increase in the U.S. current account deficit.

What are the causes of the high Chinese saving rate? A growing segment of the macro literature has focused on understanding this phenomenon. Many factors have been proposed as possible causes, including rapid income growth, aging population, lack of social safety nets and unemployment insurance, precautionary saving motives, cultural tradition of thrift, high costs of education and health care, and rising housing prices, among others. ${ }^{5}$ In particular, Wei and Zhang (2011) propose that the unbalanced sex ratio in China leads to competitive saving behavior in the marriage markets, which may significantly raise the aggregate household saving rate because men with adequate wealth accumulation (e.g., enough savings to buy houses) have a greater chance to attract marriage partners. Such competitive behavior can drive up housing prices and further reinforce the competitive saving behavior. Chamon and Prasad (2010) argue that the rapidly rising private burdens of housing, education, and health care are the most important contributing factors. They also conjecture that the impact of these factors on saving can be amplified by underdeveloped financial and credit markets.

Indeed, the rapidly rising housing prices and other costs of living (such as education and health care) in China have become serious socioeconomic problems and have attracted much attention from news media and policymakers. In Beijing and Shanghai, for example, the average housing price-to-income ratio (for a 30 -square-meter living space) is about $12 .^{6}$ That is, a young married couple needs to save their entire income (a 100\% saving rate) for 12 years to afford a 60 -square-meter apartment for their family. ${ }^{7}$ This means that, even with bank loans with a one-third

\footnotetext{
4 From a speech by Alan Greenspan, "The Fed Didn't Cause the Housing Bubble," Wall Street Journal, March 1, 2009.

5 This literature includes Carroll, Overland, and Weil (2000), Chamon and Prasad (2010), Chen, Imrohoroglu and Imrohoroglu (2006), Horioka and Wan (2007), Modigliani and Cao (2004), Song and Yang (2010), Wei and Zhang (2011), Wen $(2009,2011)$, and Yuan and Song $(1999,2000)$, among many others.

${ }^{6}$ According to the China Statistical Yearbook (2007), in 2006 the average living space per person was 27.1 square meters in urban areas and 30.7 square meters in rural areas. However, the average living space for new homebuyers is greater than 30 square meters.

7 According to China Statistical Yearbook (2008), in 2007 the nationwide average housing price was 3,645 yuan
} 
down-payment arrangement and a 33\% household saving rate, a typical working couple still needs to save for 12 years to buy a small apartment. Hence, it is not surprising that rising housing prices have been perceived as one of the most important factors underlying China's high aggregate household saving rate, especially the rapid accumulation of financial wealth in terms of bank deposits.

But can rising housing prices really explain the high household saving rate in China? This is not only an empirical question, but also a theoretical one with broad policy implications for both developing and developed economies (housing bubbles have been a common feature for both developed and developing countries in recent decades).

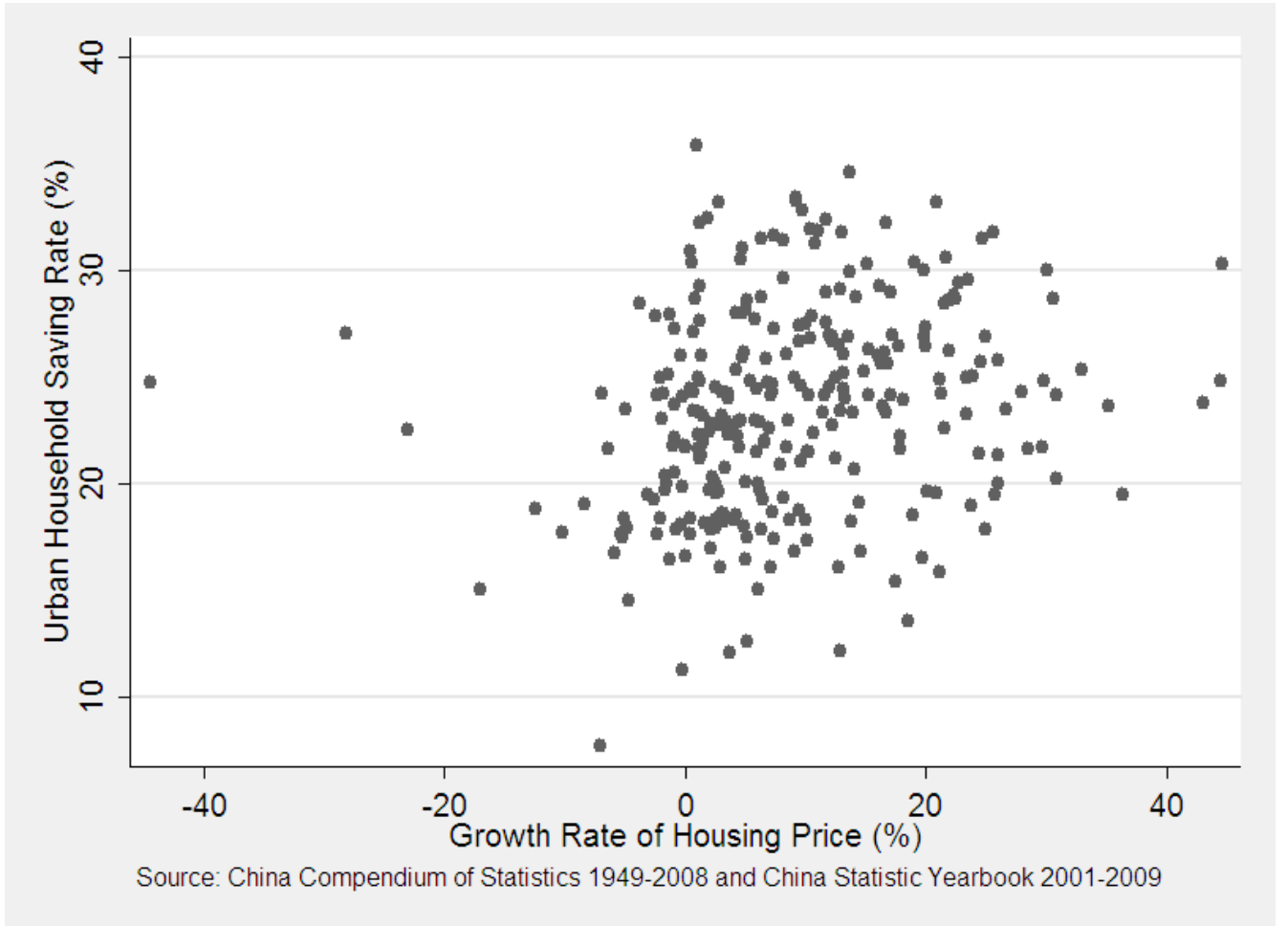

Figure 3. Saving Rate and Growth Rate of Housing Price (1999-2008)

Based on the available regional data from China, we find that the correlation between the aggregate household saving rate in a province and the growth rate of housing prices (or the housing price level) in that province is weak. This correlation is

per square meter, 10,661 yuan for Beijing and 8,253 yuan for Shanghai. In 2007, the average disposable income per capita was 13,786 yuan nationwide, 21,989 yuan in Beijing and 23,623 yuan in Shanghai. Hence, if the living space per person is 30 square meters, the housing price-to-disposable income ratio would be 7.93 for the nation, 14.55 for Beijing, and 10.48 for Shanghai. 
occasionally positive in some years but negative in others. So the average correlation in the entire 1999-2008 sample period is only slightly positive (Figure 3) but economically insignificant: An additional 10 percentage points growth rate in housing prices can raise the household saving rate by 0.49 percentage points in a OLS regression. ${ }^{8}$ Even if we delete the 3 outlier-provinces with saving rate below $-20 \%$, the correlation remains insignificant—an additional 10 percentage points increase in housing-price growth rate can raise the household saving rate by 0.69 percentage points. The result is similar if we use gross saving rates (measured as 1 minus the regional consumption-to-regional output ratio). Therefore, our empirical findings suggest that rising housing prices do not significantly contribute to the aggregate saving rate.

Given that housing finance is generally perceived as one of the biggest financial burdens in China, why do rising housing prices have such a small impact on the saving rate? To the best of our knowledge, little theoretical analysis has been carried out to carefully and quantitatively address this question. This paper addresses this question using a simple consumption-saving model. Our theoretical and quantitative simulation analyses lead to the following results:

- In a stationary economy with constant population, income, and housing prices, the aggregate household saving rate is independent of the level of housing prices.

- Rising housing prices can significantly increase the aggregate household saving rate under the following combined conditions: (i) Agents are severely borrowing constrained with extremely low possibility of obtaining mortgage loans, (ii) the population of potential future homebuyers (called "would-be homebuyers" in this paper) increases rapidly relative to the current homebuyers over time, and (iii) housing prices rise significantly faster than household income over time. However, these conditions are inconsistent with Chinese reality. Quantitative simulations based on Chinese time-series data for household income, housing prices, demographic

\footnotetext{
${ }^{8}$ The growth rate of household disposable income is controlled for in the regression. If the household income level were also controlled for, the coefficient of housing prices would be further reduced or even negative (if regional dummies are included).
} 
structure, and mortgage down-payment requirement show that rising housing prices can contribute from minus 2 to plus 4 percentage points to the measured aggregate saving rate. These results are consistent with the empirical evidence (shown in Figure 3) that aggregate household saving rates are not systematically correlated with rising housing prices.

The intuition is simple. First, suppose the only reason to save is to buy a house. Regardless of the level of housing prices, incomes saved for future housing purchases by the future (would-be) homeowners are always canceled by housing expenditures of the current homebuyers in the measured aggregate saving ratio. If part of the expenditure is financed by bank loans against an individual buyer's future income, the average lifetime saving rate at the moment of home purchase is even negative for the homebuyer because she must continue to save in the future to repay the loans until the debt is completely repaid. Hence, if the population and housing prices are constant, the average saving rate across all cohorts at any point in time is zero and independent of housing prices, regardless of borrowing constraints.

Second, if housing prices increase over time and grow faster than income, then the population share of the would-be homebuyers is effectively increasing relative to the current homebuyers. In this case, the expenditures of the current homebuyers are unable to completely cancel the savings of the would-be homebuyers. This "population effect" can translate rising housing prices into the measured aggregate saving rate. More importantly, this population effect can be greatly magnified if households are severely borrowing constrained. Because young cohorts need to save more and for longer periods under borrowing constraints when housing prices increase, this is equivalent to a continuous and rapid expansion of the population size of the saving cohort relative to the dissaving cohort. In other words, both housing-price growth and borrowing constraints are equivalent to population growth in terms of their impact on the aggregate saving rate and these two factors reinforce each other. Under such combined population effects, housing prices may play an important role in determining the aggregate saving rate. However, if household income increases faster or at roughly the same rate as that of housing prices (as is the 
case in China), then the anticipated rising permanent income would reduce the need to save and cancels the population effects. In fact, the rapid growth in household income in China is the single most important driving force behind the country's rapidly rising housing prices. Therefore, the net effect of rising housing prices on the aggregate saving rate would be ambiguous-it is positive if and only if the population effect dominates the permanent income effect.

Hence, our analysis explains why rising housing prices per se are not the most important factor contributing to China's high household saving rate. Therefore, the main causes of the high Chinese saving rate should lie in some other dimensions. ${ }^{9}$

Hayashi’s (1986) article, "Why Is Japan's Saving Rate So Apparently High?" analyzes the possible causes of Japan's high household saving rate in the 1960-80s. His analysis includes discussions regarding the possible impact of rising housing (land) prices on Japan's household saving behavior. In particular, using cross-sectional regression analysis, Hayashi found that the average household saving rate of a given Japanese city is independent of that city's average housing prices. ${ }^{10}$ Based on this finding, Hayashi concludes that rising housing prices per se are not the cause of Japan's high household saving rate. This conclusion is similar to ours. However, Hayashi did not conduct detailed theoretical analysis to rigorously explain the point, so his conclusion is not generalizable and may not apply to China. In particular, he did not consider the possibility that under severe borrowing constraints, rapidly rising housing prices may significantly increase the aggregate household saving rate due to the population effect discussed previously.

In addition, if specific transitional dynamics caused by China's housing market reforms are taken into account, rising housing prices may generate a substantial surge in the aggregate saving rate in the short run if future homebuyers could not start housing

\footnotetext{
${ }^{9}$ A prominent example is uncertainty. If there is a positive probability that the savings made for a home purchase are not spent in one's lifetime because of miscalculations or accidental death, then the aggregate housing expenditures cannot completely cancel the aggregate savings made for that purpose. However, such uncertainty is more relevant for medical expenditures than for housing purchases (see Chamon and Prasad, 2011; and Wen, 2011).

${ }^{10}$ Hayashi also estimated the saving rates of the homeowners, the would-be homebuyers, and the non-homeowners who do not plan to own houses in rural and urban areas, respectively. He argued that if housing prices have significant impact on a household's saving rate, then the saving rate of the would-be homebuyers should be significantly higher than the other two types of households, and urban households should have a higher saving rate than rural households. But he did not find such differences in the Japanese data.
} 
purchases immediately after the reform. Such transitional dynamics are also conducted in this paper using our simple model. However, we find that the timing of the predicted surge in the aggregate saving rate is inconsistent with the data, suggesting that such transitional dynamic effects are absent in China (maybe because the high saving rates of homebuyers enabled them to start housing purchases immediately after the reform, so the expenditure-saving cancellation effect could take place immediately).

The remainder of the paper is organized as follows. Section 2 presents the benchmark consumption-saving model without borrowing constraints and studies the effects of housing prices on the aggregate household saving rate. Section 3 extends the analysis to borrowing constraints. Section 4 conducts robustness analysis and considers other extensions of the basic model. Section 5 takes transitional dynamics into account. Section 6 concludes the paper with some policy recommendations.

\section{The Basic Model}

In this paper, we use a simple consumption-saving model to rationalize the empirical pattern shown in Figure 3 and Hayashi’s (1986) empirical findings for Japan. In the model, many variables (such as household income, housing prices, the optimal age of homebuyers, and demographic structure) are deliberately kept exogenous so that comparative statistics can be easily conducted using Chinese data. The only endogenous optimization behavior derived from the model is consumption smoothing over a person's lifetime subject to borrowing constraints, in accord with Friedman's (1957) permanent income hypothesis. This framework provides the simplest possible setup to calibrate the model using various Chinese time-series data without loss of generality in terms of capturing the first-order effects of housing prices on saving rates.

Complicating the model by introducing endogenous housing supply and demand is possible but such considerations would have only second-order effects on our results. First, the main impact of housing supply on saving behavior comes through housing-price changes, which are already captured by our model. Second, allowing 
for elastic housing demand means that households can opt to rent instead of buying a home when housing prices are too high, which would only enhance our conclusion because switching from purchasing a home to renting a home would reduce the need to save. In addition, the optimal timing of purchasing a home is controlled for in this paper, so robustness analysis can be conducted by varying this parameter.

\subsection{Constant Income and Housing Prices}

Suppose shelter (housing) is an indivisible and necessary consumption good that depreciates completely at the end of a homeowner's life. Given income, increases in housing prices will force individual consumers to save more (and for a longer period) to afford a house. This positive association between housing prices and individual saving behavior may be why people view rising housing prices as a main cause of the high aggregate saving rate in China. However, this view suffers from the fallacy of aggregation: It ignores the fact that when people purchase houses, they generate negative savings to society, thereby canceling other people's positive savings. ${ }^{11}$

Formally, imagine an economy where all agents have the same momentary utility function, and a typical consumer lives for $T$ periods with a constant income flow $\bar{Y}$ in each period. For simplicity, assume that (i) the interest rate is zero and there is no discounting in the future, (ii) each individual's only purpose for saving at a young age is to buy a house in middle age, and (iii) there are no debts or bequests at birth or after death. ${ }^{12}$ Suppose the consumer needs to buy a house in the beginning of period $t+1 \leq T,{ }^{13}$ the price of a house is $M>\bar{Y}$, and there are no borrowing constraints except the zero-debt requirement and the assumption of $100 \%$ depreciation of a house at the end of a homeowner's life. Also assume $T \bar{Y}>M$ to ensure that each consumer is able to afford a house with her lifetime income. ${ }^{14}$ The maximization problem is

\footnotetext{
11 Alternatively, we can convert the one-time housing expenditures into future rents as in Hayashi (1986). Since owning a home eliminates the need to pay rents in the future, it reduces the homeowner's average lifetime saving rate by exactly the same amount as treating housing expenditures as a one-time negative savings.

${ }^{12}$ Our results are robust to these assumptions.

${ }^{13}$ Because $t$ can take arbitrary values, it can be calibrated using Chinese data. Making it endogenous complicates the analysis dramatically without additional gains. An additional advantage of keeping $t$ exogenous is that we need not worry about how and when housing enters the utility function. That is, we can ignore the utility value of housing without loss of generality.

${ }^{14}$ Notice that we have deliberately omitted housing consumption in the utility function to simplify the analysis. This is an innocuous assumption because shelter is a necessary consumption good and the wealth effect generated from a house, if it exists, will only decrease the incentive for saving rather than increase it.
} 
stated as follows:

$$
\begin{gathered}
\max : \sum_{\tau=1}^{T} u\left(C_{\tau}\right) \\
\text { s.t.: } \sum_{\tau=1}^{T} C_{\tau}+M \leq T \bar{Y} .
\end{gathered}
$$

The optimal solution to the above program is

$$
C_{\tau}=\bar{Y}-\frac{M}{T}
$$

That is, consumption is perfectly smoothed and equals a constant. However, notice that the total expenditure in period $t+1$ equals consumption plus the housing expenditure: $C_{t+1}+M$. This typical consumer's expenditure, saving, and saving rate in each period of her lifetime are reported in Table 1.

Table 1. Individual Consumer's Saving Behavior

\begin{tabular}{cccccccc}
\hline Period & $\boldsymbol{1}$ & $\ldots$ & $\boldsymbol{t}$ & $\boldsymbol{t}+\boldsymbol{1}$ & $\boldsymbol{t}+2$ & $\ldots$ & $\boldsymbol{T}$ \\
\hline Expenditure & $\bar{Y}-M / T$ & $\ldots$ & $\bar{Y}-M / T$ & $\bar{Y}-M / T+M$ & $\bar{Y}-M / T$ & $\ldots$ & $\bar{Y}-M / T$ \\
\hline Savings & $M / T$ & $\ldots$ & $M / T$ & $\frac{M}{T}-M$ & $M / T$ & $\ldots$ & $M / T$ \\
\hline \multirow{2}{*}{ Saving Rate } & $\frac{M}{T \bar{Y}}$ & $\ldots$ & $\frac{M}{T \bar{Y}}$ & $\frac{M}{T \bar{Y}}-\frac{M}{\bar{Y}}$ & $\frac{M}{T \bar{Y}}$ & $\ldots$ & $\frac{M}{T \bar{Y}}$ \\
\hline
\end{tabular}

The first row of Table 1 indicates the consumer's living period (or age), the second row total expenditures in each period, the third row additional savings in each period, and the last row the saving rate in each period, which is defined as the ratio of additional savings to disposable income. The table shows that the consumer's average lifetime saving rate is given by $\sum_{\tau=1}^{T} \frac{M}{T \bar{Y}}-\frac{M}{\bar{Y}}=0$.

To compute the "aggregate household saving rate" in this economy with $T$ different age cohorts in a particular period, we need to aggregate the saving rates of all age cohorts in that period. There exist two measures (or definitions) of the cross-sectional aggregate saving rate: 
(i) It is given by the average of the personal saving rate across cohorts weighted by the population share of each age cohort-namely,

$$
\bar{S}=\sum_{\tau=1}^{T} \alpha_{\tau} s_{\tau}
$$

where $\alpha_{\tau}$ represents the population share of cohort $\tau$ in the total population, and $s_{\tau}=\frac{S_{\tau}}{Y_{\tau}}$ represents the saving rate of cohort $\tau$.

(ii) It is given by the ratio of aggregate savings to aggregate income in the same period:

$$
\bar{S}=\frac{\sum_{\tau=1}^{T} \alpha_{\tau} S_{\tau}}{\sum_{\tau=1}^{T} \alpha_{\tau} Y_{\tau}}
$$

where $\alpha_{\tau}$ still denotes the population share of cohort $\tau, S_{\tau}$ denotes the savings of cohort $\tau$, and $Y_{\tau}$ the income of cohort $\tau$.

We call definition (i) the average household saving rate and definition (ii) the aggregate household saving rate. Clearly, if all cohorts have the same income levels and identical population shares, the two definitions are equivalent. However, if different cohorts have different income levels and population shares (e.g., because of income and population growth), the two measures of the aggregate saving rate are not identical. Because definition (ii) depends only on macro data and is consistent with the data presented in Figure 1 and 2, we adopt the definition in equation (2) as the measure of the aggregate household saving rate for the remainder of this paper.

Assume identical population shares across cohorts (we relax this assumption in a later section); then $\alpha_{\tau}=\frac{1}{T}$ in equation (2). In this case, because income and housing prices are assumed constant, we can compute the aggregate household saving rate in equation (2) using information provided in Table 1 to obtain 


$$
\bar{S}=\frac{\sum_{\tau=1}^{T} \frac{1}{T} S_{\tau}}{\sum_{\tau=1}^{T} \frac{1}{T} Y_{\tau}}=\frac{\left(\sum_{\tau=1}^{T} \frac{M}{T}\right)-M}{\sum_{\tau=1}^{T} \bar{Y}}=0
$$

Namely, the aggregate saving rate is zero and independent of housing prices.

Hence, under the maintained assumptions of constant income and demographics, changes in the level of housing prices do not affect the aggregate saving rate, although they do affect each individual's saving rate in a particular period. In other words, even if $99 \%$ of the total population reports that they are saving for future home purchases, the other $1 \%$ of the population (the current homebuyers) can generate just enough negative savings to cancel the others' positive savings, resulting in a zero aggregate saving rate. This logic of aggregation is simple but not always recognized.

However, the conclusion no longer holds if income and housing prices grow over time. Continuously rising housing prices imply that young cohorts must continuously increase their saving rate and save for a longer period to afford a house. Consequently, the relative population share of the would-be homebuyers will become effectively larger than that of current homebuyers (even without population growth) and this population effect may result in a higher aggregate saving rate.

\subsection{Time-Varying Income and Housing Prices}

In a model with time-varying income and housing prices, a consumer born in period 1 who needs to purchase a house in period $t+1$ solves the following problem:

$$
\begin{gathered}
\max : \sum_{\tau=1}^{T} u\left(C_{\tau}\right) \\
\text { s.t.: } \sum_{\tau=1}^{T} C_{\tau}+M_{t+1} \leq \sum_{\tau=1}^{T} Y_{\tau} .
\end{gathered}
$$

The optimal solution is given by

$$
C_{\tau}=\bar{Y}-\frac{M_{t+1}}{T}
$$

where $\bar{Y}=\frac{1}{T} \sum_{\tau=1}^{T} Y_{\tau}$ denotes a consumer's permanent income (i.e., average lifetime 
income). Note that total expenditure in period $t+1$ is $C_{t+1}+M_{t+1}$.

Suppose the optimal age for each consumer to become a homeowner is $t+1$ periods after birth. Suppose at the present moment this cohort of current homebuyers faces housing price $M_{0}$ and has permanent income $\bar{Y}_{0}$. We call this age group "cohort $t+1$." Based on such notations, the generation one period younger than the current homebuyer cohort is called "cohort $t$," who will become homebuyers in the next period and face housing price $M_{1}$ and permanent income $\bar{Y}_{1}$. Analogously, the generation one period older than the current homebuyers is called "cohort $t+2$," who already bought a house one period ago when the housing price was $M_{-1}$ and permanent income was $\bar{Y}_{-1}$. Similarly, at the present moment all generations younger than the current homebuyers are called cohorts $\{1,2, \ldots, t\}$, respectively, and these would-be homebuyers will face housing prices $\left\{M_{t}, M_{t-1}, \ldots, M_{1}\right\}$ and permanent income $\left\{\bar{Y}_{t}, \bar{Y}_{t-1}, \ldots, \bar{Y}_{1}\right\}$, respectively, when they purchase homes in the future. Also, at the moment all generations older than the current homebuyers are called cohorts $\{t+2, t+3, \ldots, T\}$, respectively, and each person in these cohorts bought a house with respective prices $\left\{M_{-1}, M_{-2}, \ldots, M_{-T+t+1}\right\}$ and permanent income $\left\{\bar{Y}_{-1}, \bar{Y}_{-2}, \ldots, \bar{Y}_{-T+t+1}\right\}$ in the past.

Table 2. Saving Behavior of Different Age Cohorts

\begin{tabular}{cccccccc}
\hline Age Cohort & $\boldsymbol{1}$ & $\ldots$ & $\boldsymbol{t}$ & $\boldsymbol{t}+\boldsymbol{1}$ & $\boldsymbol{t}+\mathbf{2}$ & $\ldots$ & $\boldsymbol{T}$ \\
\hline $\begin{array}{c}\text { Permanent } \\
\text { Income }\end{array}$ & $\bar{Y}_{t}$ & $\ldots$ & $\bar{Y}_{1}$ & $\bar{Y}_{0}$ & $\bar{Y}_{-1}$ & $\ldots$ & $\bar{Y}_{-T+t+1}$ \\
\hline $\begin{array}{c}\text { Housing } \\
\text { Price }\end{array}$ & $M_{t}$ & $\ldots$ & $M_{1}$ & $M_{0}$ & $M_{-1}$ & $\ldots$ & $M_{-T+t+1}$ \\
\hline Savings & $M_{t} / T$ & $\ldots$ & $M_{1} / T$ & $\frac{(1-T) M_{0}}{T}$ & $M_{-1} / T$ & $\ldots$ & $M_{-T+t+1} / T$ \\
\hline Saving Rate & $\frac{M_{t}}{T \bar{Y}_{t}}$ & $\ldots$ & $\frac{M_{1}}{T \bar{Y}_{1}}$ & $\frac{(1-T) M_{0}}{T \bar{Y}_{0}}$ & $\frac{M_{-1}}{T \bar{Y}_{-1}}$ & $\ldots$ & $\frac{M_{-T+t+1}}{T \bar{Y}_{-T+t+1}}$ \\
\hline
\end{tabular}


Based on the above notations, we can tabulate the incomes, savings, and saving rates of different age cohorts at the present moment (Table 2). The first row in Table 2 shows the age of different cohorts at the present moment, the second row their respective permanent income levels, the third row the housing price they face when becoming a homeowner, the fourth row their current level of savings, and the last row their respective saving rate at the present moment. The table shows that at the same time point different age cohorts have different saving rates because permanent income and housing prices are changing over time. However, regardless of the age cohort, the saving rate of each cohort is always a function of the housing price-to-income ratio $(M / \bar{Y})$ facing that particular cohort.

Therefore, if the price-to-income ratio remains constant over time despite growing housing prices and permanent income, then different age cohorts (except the current homebuyer cohort) have the same saving rate, whereas the current homebuyer cohort always has a negative saving rate that offsets the positive savings of the other cohorts. Hence, the average saving rate across cohorts is exactly zero because each cohort is weighted identically by the factor $1 / T$ in computing the societal average saving rate (see the last row in Table 2).

However, if the housing price-to-income ratio changes over time, the measured aggregate saving rate is not necessarily zero but depends on the difference between the current homebuyers' housing price-to-income ratio and the other cohorts' average housing price-to-income ratio. Hence, the measured aggregate saving rate can be either positive or negative.

To sort out these effects, consider first the case where permanent income and housing prices have constant growth rates according to the equations $\bar{Y}_{\tau}=(1+a) \bar{Y}_{\tau-1}$ and $M_{\tau}=(1+b) M_{\tau-1}$, respectively, where the growth rate $a$ and $b$ are both constants. Notice that if annual income grows at a constant rate, then the permanent income also grows at the same constant rate. Under these conditions, the aggregate saving rate is given by 


$$
\bar{S}=\frac{\sum_{\underline{\underline{\tau}}=-T+t+1}^{t} \frac{1}{T} S_{\tau}}{\sum_{\tau=-T+t+1}^{t} \frac{1}{T} \bar{Y}_{\tau}} \frac{\left(\sum_{\tau=-T+t+1}^{t} \frac{M_{0}(1+b)^{\tau}}{T}\right)-M_{0}}{\sum_{\tau=T+4}^{t} \bar{Y}_{0}(1+a)^{\tau}}
$$

If $a \neq 0$ and $b \neq 0$, equation (4) can be simplified to

$$
\bar{S}=\frac{M_{0}}{\bar{Y}_{0}} \frac{\frac{(1+b)^{-T+t+1}}{T} \frac{\left[1-(1+b)^{T}\right]}{1-(1+b)}-1}{(1+a)^{-T+t+1} \frac{\left[1-(1+a)^{T}\right]}{1-(1+a)}},
$$

which depends only on the price-to-income ratio of the current homebuyer cohort and is clearly not zero. For example, suppose $a=b=10 \%, T=40$, and $t=15$. $^{15}$ Then equation (4) gives an aggregate saving rate of $2.14 \%$, which is small compared with the above $20-25 \%$ Chinese household saving rate. ${ }^{16}$

Calibration 1. We now use actual Chinese time-series data to calibrate the model. Suppose that people start working at age 21 and retire at age 60; thus, we set the total working years $T=40$. Also suppose that the average homebuyer's age is 35 -that is, people must work and save for 15 years before buying a house. This implies that $t=$ 15 in our model. Suppose that individuals in the current homebuyer cohort ("cohort $t+1$ ") become homeowners in the year 2007; in that year the housing price-to-income ratio in China was 7.93, so we set $M_{0} / \bar{Y}_{0}=8$. According to the Chinese Statistical Yearbook (2008), from 1978 to 2007 the growth rate of average family income is $12.57 \%$ in rural areas and $13.58 \%$ in urban areas; hence we set $a=0.13$. According to the China Macroeconomic Information Network Database, the average growth rate of housing prices was $9.02 \%$ per year between 1991 and 2008, hence we set $b=0.09$. Entering these numbers into equation (4), the estimated aggregate saving rate equals 1\%. That is, rising housing prices explain only 1 percentage point of China's aggregate household saving rate, substantially below the actual $20 \%$ saving rate in

\footnotetext{
${ }^{15} T=40$ and $t=15$ imply that each individual needs to work for 15 years to afford a house and work for 40 years to retire (income is assumed to be zero after retirement).

${ }^{16}$ On the other hand, it is possible to obtain an aggregate saving rate of $20 \%$ in the model if we allow the growth rate of permanent income and housing prices to be $50 \%$ per year in the steady state. But such a rapid growth rate is hard to imagine in reality.
} 
2007.

Moreover, even if the growth rate of housing prices exceeds that of income, the impact of rising housing prices on aggregate saving rate is still quite limited. For example, when the growth rate of household income is $10 \%$ per year, to reach an aggregate saving rate of $20 \%$ in the model, the average growth rate of housing prices must be about $20 \%$ per year. Although a $20 \%$ annual growth rate in housing prices is possible for a short period or for a particular district of a city, we have not seen such a high aggregate growth rate over a 10 -year period in China or anywhere else in the world.

Calibration 2. The previous calibration analysis is based on the assumption that the growth rates of income and housing prices are constant over time. If we allow the growth rate of income and housing prices to be stochastic over time, how does this affect our results? Because the simple model is no longer analytically tractable under uncertainty, we assume perfect foresight to gain intuition. When the growth rates of both income and housing prices are time varying, Table 2 implies that the aggregate household saving rate is determined by

$$
\bar{S}=\frac{\frac{1}{T} \sum_{\tau=-T+t+1}^{t} M_{\tau}-M_{0}}{\sum_{\tau=-T+t+1}^{t} \bar{Y}_{\tau}} .
$$

As before, using 2007 as the base year for the current homebuyers (cohort $t+1$ ), $M_{0}=P_{2007}$, where $P_{2007}$ denotes the average housing price in 2007. We use a 40-year window to compute the permanent income based on 40 years of average household income between year $2007-t$ and year $2007+T-t-1$, where $T=40$. For example, the permanent income of cohort $t+1$ is given by $\bar{Y}_{0}=\frac{1}{T} \sum_{j=2007-t}^{2007+T-t-1} Y_{j}$. By the same method, we can also estimate the permanent incomes of cohorts $\{1,2, \ldots, t\}$ and cohorts $\{t+2, t+3, \ldots, T\} .{ }^{17}$ Entering the estimated values of housing prices facing

\footnotetext{
${ }_{17}$ Computing young cohorts' permanent income needs to use income data after 2009. Since such data do not exist, we extrapolate by assuming a 10\% annual growth rate after 2009 .
} 
homebuyers of different age cohorts, $\left\{M_{t}, M_{t-1}, \ldots, M_{0}, \ldots, M_{-T+t+1}\right\}$, and the corresponding permanent incomes, $\left\{\bar{Y}_{t}, \bar{Y}_{t-1}, \ldots, \bar{Y}_{0}, \ldots, \bar{Y}_{-T+t+1}\right\}$, into equation (5), we obtain an aggregate saving rate of $0.61 \%$. Therefore, regardless of how the model is calibrated, we conclude that in the absence of borrowing constraints, rising housing prices cannot significantly affect China's aggregate household saving rate.

\section{Borrowing Constraints and Demographics}

Our basic model makes two important assumptions: (i) Consumers can completely smooth their consumption over a working lifetime by using future income to finance current mortgage payments. (ii) The population or demographic structure does not change over time. These assumptions are not realistic and may bias our results.

Assumption (i) would be innocuous if household income, housing prices, and population were constant over time. To understand this point, suppose consumers cannot borrow at all. Then cohort $t+1$ must increase its saving rate at a younger age to accumulate just enough money to pay off the entire mortgage before period $t+1$. In this case, the aggregate saving rate is still zero because the negative savings generated by cohort $t+1$ in the housing market still completely cancel the total positive savings from cohorts $\{1,2, \ldots, t\}$. However, if income and housing prices grow over time, assumption (i) is no longer innocuous and borrowing constraints may magnify the positive impact of housing prices on the aggregate saving rate.

The assumption of a constant population size does not allow our model to capture any demographic changes and the impact of such changes on the aggregate saving rate. Hence, taking into account the demographic structure is also important for the robustness of our analysis and conclusions. Formal analyses with the assumptions (i) and (ii) relaxed are presented below. We consider first the case with borrowing constraints (Section 3.1) and then the case with a time-varying population structure (Section 3.2). 


\subsection{With Borrowing Constraints}

To facilitate the analysis, we first consider constant income and housing prices under borrowing constraints. If agents cannot borrow at all and the optimal timing for purchasing a home is still $t+1$ periods after birth (or starting to work), the would-be homebuyers must then increase their saving rates before period $t+1$ to purchase a house with the same price. This implies that from period 1 to $t$ the saving rate is $M / t$, and optimal consumption is $\bar{Y}-M / t$. Between period $t+2$ and period $T$, the optimal consumption level is $\bar{Y}$ and the saving rate is zero. In period $t+1$, total expenditure (consumption plus housing purchase) is $\bar{Y}+M$. These statistics are summarized in Table 3.

Table 3. Individual Saving Behavior under Borrowing Constraints

\begin{tabular}{cccccccc}
\hline Period & $\boldsymbol{1}$ & $\ldots$ & $\boldsymbol{t}$ & $\boldsymbol{t}+\boldsymbol{1}$ & $\boldsymbol{t}+2$ & $\ldots$ & $\boldsymbol{T}$ \\
\hline Expenditure & $\bar{Y}-M / t$ & $\ldots$ & $\bar{Y}-M / t$ & $\bar{Y}+M$ & $\bar{Y}$ & $\ldots$ & $\bar{Y}$ \\
\hline Saving & $M / t$ & $\ldots$ & $M / t$ & $-M$ & 0 & $\ldots$ & 0 \\
\hline \multirow{2}{*}{ Saving Rate } & $\frac{M}{t \bar{Y}}$ & $\ldots$ & $\frac{M}{t \bar{Y}}$ & $\frac{-M}{\bar{Y}}$ & 0 & $\ldots$ & 0 \\
\hline
\end{tabular}

Compared with Table 1, borrowing constraints raise the individual's saving rate from $M / T$ to $M / t$; however, the average lifetime saving rate is still zero. Hence, if the population share of each age cohort is the same, the aggregate saving rate is also zero.

Now with time-varying income and housing prices, the effective share of each cohort is no longer the same because of the population effect. In this case, we can use a method similar to that used for Table 2 to compute each age cohort's saving rate under borrowing constraints. These results are summarized in Table 4.

Table 4. Saving Behavior of Different Cohorts under Borrowing Constraints

\begin{tabular}{|c|c|c|c|c|c|c|c|}
\hline Age Cohort & 1 & $\ldots$ & $t$ & $t+1$ & $t+2$ & $\ldots$ & $T$ \\
\hline
\end{tabular}




\begin{tabular}{cccccccc}
\hline $\begin{array}{c}\text { Permanent } \\
\text { Income }\end{array}$ & $\bar{Y}_{t}$ & $\ldots$ & $\bar{Y}_{1}$ & $\bar{Y}_{0}$ & $\bar{Y}_{-1}$ & $\ldots$ & $\bar{Y}_{-T+t+1}$ \\
\hline $\begin{array}{c}\text { Housing } \\
\text { Price }\end{array}$ & $M_{t}$ & $\ldots$ & $M_{1}$ & $M_{0}$ & $M_{-1}$ & $\ldots$ & $M_{-T+t+1}$ \\
\hline Saving & $M_{t} / t$ & $\ldots$ & $M_{1} / t$ & $-M_{0}$ & 0 & $\ldots$ & 0 \\
\hline Saving Rate & $\frac{M_{t}}{t \bar{Y}_{t}}$ & $\cdots$ & $\frac{M_{1}}{t \bar{Y}_{1}}$ & $\frac{-M_{0}}{\bar{Y}_{0}}$ & 0 & $\ldots$ & 0 \\
\hline
\end{tabular}

As before, in a particular moment, the current homebuyer generation is called cohort $t+1$, and this cohort faces housing price $M_{0}$ and permanent income $\bar{Y}_{0}$. The one-period-younger generation is called cohort $t$; this cohort will be buying houses in the next period, facing housing price $M_{1}$ and permanent income $\bar{Y}_{1}$, and this generation's current saving rate is $M_{1} / t \bar{Y}_{1}$. Analogously, the one-period-older generation is called cohort $t+2$; these individuals have already bought houses in the last period, faced housing price $M_{-1}$ and permanent income $\bar{Y}_{-1}$, and this generation's current saving rate is 0 , in contrast to the model in Table 2. All cohorts proceed in a similar fashion.

Suppose permanent income and housing prices grow over time according to the equations $\bar{Y}_{\tau}=(1+a) \bar{Y}_{\tau-1}$ and $M_{\tau}=(1+b) M_{\tau-1}$, respectively, the aggregate saving rate under borrowing constraints is given by

$$
\bar{S}=\frac{\sum_{\tau=1}^{t} \frac{M_{0}(1+b)^{\tau}}{t}-M_{0}}{\sum_{\tau=-T+t+1}^{t} \bar{Y}_{0}(1+a)^{\tau}},
$$

which can be simplified to

$$
\bar{S}=\frac{M_{0}}{\bar{Y}_{0}} \frac{\frac{(1+b)}{t} \frac{\left[1-(1+b)^{t}\right]}{1-(1+b)}-1}{(1+a)^{-T+t+1} \frac{\left[1-(1+a)^{T}\right]}{1-(1+a)}} .
$$


Alternatively, if the growth rates of income and housing prices are stochastic over time (as in actual Chinese data), under the assumption of perfect foresight, the aggregate saving rate is given by

$$
\bar{S}=\frac{\frac{\sum_{\tau=1}^{t} M_{\tau}}{t}-M_{0}}{\sum_{\tau=-T+t+1}^{t} \bar{Y}_{\tau}} .
$$

In either case, the aggregate saving rate under borrowing constraints is larger than that without borrowing constraints (because $t<T$ ). Without borrowing constraints, when housing prices increase, the average saving rate of would-be homebuyers is larger than the absolute saving rate of the current homeowners because of the population effect. With borrowing constraints, however, this population effect is significantly amplified because the saving rate of all past homebuyers (i.e., the current homeowners) is now zero. In other words, in computing aggregate savings, the population weight of the would-be homebuyers is increased from $1 / T$ to $1 / t$, while the population weight of the past homebuyers is decreased from $1 / T$ to 0 . Consequently, the ratio of aggregate savings to aggregate income (the aggregate saving rate) is increased by borrowing constraints.

Following Calibration 1 in Section 2.2, equation (6) gives an aggregate saving rate of $16.66 \%$. Alternatively, following Calibration 2 in equation (7) gives an aggregate saving rate of $19.22 \%$. Clearly, under severe borrowing constraints (i.e., no borrowing at all), actual Chinese time-series data for housing prices and income would imply estimates of the aggregate saving rate that match the actual Chinese household saving rate quite well. It thus appears that rising housing prices can indeed explain China's high household saving rate if borrowing constraints are taken into account.

In reality, however, the degrees of borrowing constraints are not as severe as assumed in the above analysis. Typically, homebuyers need to pay only one-third of the housing price as a down payment and can borrow at least two-thirds with the 
mortgage. In addition, many homebuyers in China are from the rich class and often pay off the entire mortgage without requiring bank loans at all. But how would a slightly relaxed borrowing constraint affect our quantitative result?

Table 5. Individual's Saving Behavior with 50\% Down Payment

\begin{tabular}{cccccccc}
\hline Period & 1 & $\ldots$ & \multicolumn{1}{c}{$\boldsymbol{t}$} & $\boldsymbol{t}+\boldsymbol{1}$ & $\boldsymbol{t}+2$ & $\ldots$ & $\boldsymbol{T}$ \\
\hline Expenditure & $\bar{Y}-M / 2 t$ & $\ldots$ & $\bar{Y}-M / 2 t$ & $\bar{Y}-\frac{M}{2(T-t)}+M$ & $\bar{Y}-\frac{M}{2(T-t)}$ & $\ldots$ & $\bar{Y}-\frac{M}{2(T-t)}$ \\
\hline \multirow{2}{*}{ Saving } & $M / 2 t$ & $\ldots$ & $M / 2 t$ & $\frac{M}{2(T-t)}-M$ & $\frac{M}{2(T-t)}$ & $\ldots$ & $\frac{M}{2(T-t)}$ \\
\hline Saving Rate & $\frac{M}{2 t \bar{Y}}$ & $\ldots$ & $\frac{M}{2 t \bar{Y}}$ & $\frac{M}{2(T-t) \bar{Y}}-\frac{M}{\bar{Y}}$ & $\frac{M}{2(T-t) \bar{Y}}$ & $\ldots$ & $\frac{M}{2(T-t) \bar{Y}}$ \\
\hline
\end{tabular}

Table 6. Saving Behavior of Different Cohorts with 50\% Down Payment

\begin{tabular}{cccccccc}
\hline Age Cohort & $\boldsymbol{1}$ & $\ldots$ & $\boldsymbol{t}$ & $\boldsymbol{t}+\boldsymbol{1}$ & $\boldsymbol{t}+2$ & $\ldots$ & $\boldsymbol{T}$ \\
\hline $\begin{array}{c}\text { Permanent } \\
\text { Income }\end{array}$ & $\bar{Y}_{t}$ & $\ldots$ & $\bar{Y}_{1}$ & $\bar{Y}_{0}$ & $\bar{Y}_{-1}$ & $\ldots$ & $\bar{Y}_{-T+t+1}$ \\
\hline $\begin{array}{c}\text { Housing } \\
\text { Price }\end{array}$ & $M_{t}$ & $\ldots$ & $M_{1}$ & $M_{0}$ & $M_{-1}$ & $\ldots$ & $M_{-T+t+1}$ \\
\hline Saving & $M_{t} / 2 t$ & $\ldots$ & $M_{1} / 2 t$ & $\frac{M_{0}}{2(T-t)}-M_{0}$ & $\frac{M_{-1}}{2(T-t)}$ & $\ldots$ & $\frac{M_{-T+t+1}}{2(T-t)}$ \\
\hline Saving Rate & $\frac{M_{t}}{2 t \bar{Y}_{t}}$ & $\ldots$ & $\frac{M_{1}}{2 t \bar{Y}_{1}}$ & $\frac{M_{0}}{2(T-t) \bar{Y}_{0}}-\frac{M_{0}}{\bar{Y}_{0}}$ & $\frac{M_{-1}}{2(T-t) \bar{Y}_{-1}}$ & $\ldots$ & $\frac{M_{-T+t+1}}{2(T-t) \bar{Y}_{-T+t+1}}$ \\
\hline
\end{tabular}

To be conservative, assume that the down-payment requirement is as high as $50 \%$ of the house price. ${ }^{18}$ In this case, the borrowing constraints may not bind if each generation's optimal time for buying a house is after working for 20 years (because of sufficient savings). However, as long as each generation still needs to purchase houses after working only for 15 years (as assumed before), borrowing constraints will still

\footnotetext{
18 In China the down payment required for home loans has been about one-third of the purchase price regardless of the number of homes people purchase. Currently the down payment for the first house is one-third and that for the second house is $50 \%$ (some people in China own more than one home for investment purposes).
} 
bind for every generation with an empirically plausible growth rate of income and housing prices. Under these conditions, a typical individual's saving behavior is shown in Table 5 and the saving behavior across cohorts is shown in Table 6 .

Table 5 shows that between period 1 and period $t$ of an individual's lifetime, a consumer's annual saving is $M / 2 t$; in period $t+1$, the total past savings are just enough to pay for the $50 \%$ down payment, so the consumer needs to borrow the other $50 \%$ from future income to pay for the mortgage. Thus, in period $t+1$ the buyer's housing expenditure is $M$ and saving is $\frac{M}{2(T-t)}-\mathrm{M}$; afterward, future saving for each period is always $\frac{M}{2(T-t)}$.

Based on such information and assuming that permanent income and housing prices follow a constant growth rule, $\bar{Y}_{\tau}=(1+a) \bar{Y}_{\tau-1}$ and $M_{\tau}=(1+b) M_{\tau-1}$, then the aggregate saving rate is given by

$$
\bar{S}=\frac{\sum_{\tau=1}^{t} \frac{M_{0}(1+b)^{\tau}}{2 t}+\sum_{\tau=T * \sharp}^{0} \frac{M_{0}(1+b)^{\tau}}{2(T-t)}-M_{0}}{\sum_{\tau=-T+t+1}^{t} \bar{Y}_{0}(1+a)^{\tau}} .
$$

In such a case, Calibration 1 implies an aggregate saving rate of $4.17 \%$.

Alternatively, if the growth rates of income and housing prices are stochastic, under perfect foresight the aggregate saving rate is given by

$$
\bar{S}=\frac{\frac{\sum_{\tau=1}^{t} M_{\tau}}{2 t}+\frac{\sum_{\tau=T+t}^{0} M_{\tau}}{2(T-t)}-M_{0}}{\sum_{\tau=-T+t+1}^{t} \bar{Y}_{\tau}}
$$

In this case, Calibration 2 implies an aggregate saving rate of $4.34 \% .^{19}$

We can thus make the following conclusions from the above analyses: Borrowing constraints can significantly amplify the positive population effects of

\footnotetext{
19 In the case of a $40 \%$ down payment, the saving rate becomes $1.64 \%$.
} 
rising housing prices on the aggregate saving rate. However, with realistic borrowing constraints, the effects of rising housing prices on the aggregate saving rate are still minimal, at most 2 to 4 percentage points. These values are nontrivial, but not large enough to explain China's over $25 \%$ saving rate.

Our analysis also indicates that, relative to rising housing prices (or other costs of living), borrowing constraints may be a more important factor in explaining China's high household saving rate. This also explains why more than a decade of rising housing prices in the United States before the recent financial crisis did not induce a high household saving rate: American families are much less borrowing constrained than Chinese households.

\subsection{With Demographic Changes}

As with income and housing price changes, a changing population should have little impact on the aggregate saving rate without borrowing constraints. Thus, this section considers only cases with borrowing constraints.

If the population changes over time, the population weights $\alpha_{\tau}$ in equation (2) for different cohorts must be adjusted accordingly when computing the aggregate saving rate. Thus, letting $W_{\tau}$ denote cohort $\tau$ 's share in the total population and assuming that permanent income and housing prices follow the equations $\bar{Y}_{\tau}=(1+a) \bar{Y}_{\tau-1}$ and $M_{\tau}=(1+b) M_{\tau-1}$, then the aggregate saving rate (with complete borrowing constrains) based on equation (2) is given by

$$
\bar{S}=\frac{\sum_{\tau=1}^{t} W_{\tau} \frac{M_{0}(1+b)^{\tau}}{t}-W_{0} M_{0}}{\sum_{\tau=-T+t+1}^{t} W_{\tau} \bar{Y}_{0}(1+a)^{\tau}},
$$

which is analogous to equation (6).

Based on the population shares of individuals age 21 to age 60 provided in the China Population and Employment Statistics Yearbook (2008), assuming that working ages are from 21 to 60 , the average homebuyer's age is 35 ; using the average income growth and housing price growth in China, equation (10) implies an aggregate saving 
rate of $10.47 \%$, lower than the value under constant population. However, if we allow a 50\% down payment for the mortgage, the implied aggregate saving rate is negative $(-0.75 \%)$, also lower than the value with constant population.

Alternatively, if we allow the growth rates of income and housing prices to vary over time, under $100 \%$ borrowing constraints (100\% down payment), the aggregate saving rate is given by

$$
\bar{S}=\frac{\sum_{\tau=1}^{t} W_{\tau} \frac{M_{\tau}}{t}-W_{0} M_{0}}{\sum_{\tau=-T+t+1}^{t} W_{\tau} \bar{Y}_{\tau}} .
$$

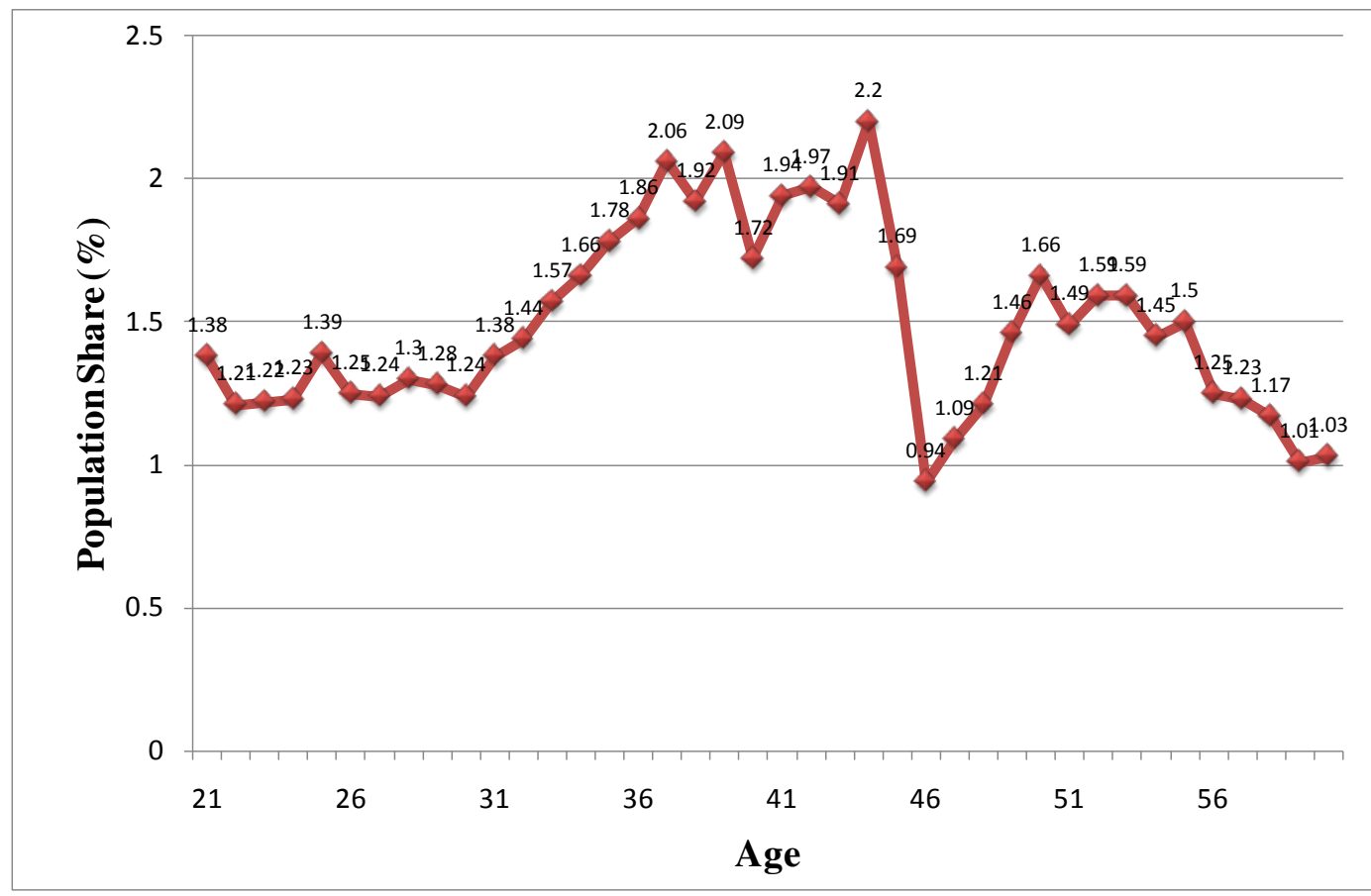

Figure 4. Population Shares of Different Age Cohorts in 2007. ${ }^{20}$

Using Calibration 2 by choosing 2007 as the base year for the homebuyer cohort, the implied aggregate saving rate is $11.32 \%$, lower than the value with constant population. If we allow a $50 \%$ down payment, the implied aggregate saving rate is $-1.62 \%$, also lower than the value with constant population.

The reason that taking the demographic structure into account yields a lower

\footnotetext{
${ }^{20}$ Data source: China Statistical Yearbook.
} 
aggregate saving rate, everything else equal, is that in recent years the current homebuyer cohort is at its peak in terms of its population share. Therefore, the savings generated by this cohort receives larger weight. Figure 4 plots the demographic structure in China. Based on China Population and Employment Statistics Yearbook (2008) and under the assumption that working ages are between 21 and 60 and the average homebuyer's age is 35, the homebuyer cohort peaked around 2007.

If the base year of the homebuyer cohort is moved to other years, such as 2005 or earlier, or if we change the assumed age of homebuyers, the implied aggregate saving rate will differ insignificantly from the values obtained above. The reason is simple: Unless the population has been sharply declining so that the population share of the current homebuyer cohort is always significantly smaller than any of the would-be homebuyer cohorts (which is inconsistent with Chinese data), taking the demographic structure into account cannot strengthen the effect of rising housing prices on the aggregate saving rate.

\subsection{Summary of Analyses}

We discussed three scenarios in the previous analyses: (i) time-varying income and housing prices, (ii) borrowing constraints, and (iii) demographic changes. The results are briefly summarized in Table 7 . The first column lists the assumptions, the second column shows the corresponding equation used to compute the aggregate saving rate, and the last column shows the implied numerical value of the aggregate saving rate. Notice that Calibration 1 applies to cases with a constant growth rate of income and housing prices and Calibration 2 applies to cases with a stochastic growth rate of income and housing prices.

The first three rows in Table 7 show that without borrowing constraints and demographic changes, rising housing prices contribute little to the aggregate saving rate: less than $1 \%$. The subsequent two rows show that under complete borrowing constraints (with zero possibility to borrow), rising housing prices can have large effects on the aggregate saving rate, ranging from $16.66 \%$ to $19.22 \%$. However, such effects are quickly dampened once the degree of borrowing constraints is reduced. For 
example, with a 50\% down-payment requirement, the aggregate saving rate is reduced to $4.17 \%$ and $4.34 \%$, respectively, depending on the specific income process. These values are further reduced to $2 \%$ if the down payment is $40 \%$. In addition, if China's demographic structure is taken into account, the last two rows in the table show that the saving rate is reduced further: down to $-0.75 \%$ and $-1.62 \%$, respectively. Therefore, given Chinese time-series data on household income, mortgage prices, borrowing costs, and demographics, we can conclude that the aggregate household saving rate is essentially unrelated to housing prices.

Table 7. Aggregate Saving Rate under Different Assumptions

\begin{tabular}{|c|c|c|}
\hline Assumptions & Equation & Saving Rate $(\%)$ \\
\hline No BC, constant $\{\mathrm{D}, \mathrm{I}, \mathrm{P}\}$ & (3) & 0.00 \\
\hline No $\mathrm{BC}$, constant $\mathrm{D}$, constant growth in $\{\mathrm{I}, \mathrm{P}\}$ & (4) & 1.00 \\
\hline No $\mathrm{BC}$, constant $\mathrm{D}$, time-varying growth in $\{\mathrm{I}, \mathrm{P}\}$ & (5) & 0.61 \\
\hline $100 \% \mathrm{BC}$, constant $\mathrm{D}$, constant growth in $\{\mathrm{I}, \mathrm{P}\}$ & $(6)$ & 16.66 \\
\hline $100 \% \mathrm{BC}$, constant $\mathrm{D}$, time-varying growth in $\{\mathrm{I}, \mathrm{P}\}$ & $(7)$ & 19.22 \\
\hline $50 \% \mathrm{BC}$, constant $\mathrm{D}$, constant growth in $\{\mathrm{I}, \mathrm{P}\}$ & $(8)$ & 4.17 \\
\hline $50 \% \mathrm{BC}$, constant $\mathrm{D}$, time-varying growth in $\{\mathrm{I}, \mathrm{P}\}$ & (9) & 4.34 \\
\hline Time-varying D, $100 \% \mathrm{BC}$, constant growth in $\{\mathrm{I}, \mathrm{P}\}$ & $(10)$ & 10.47 \\
\hline Time-varying D and growth in $\{\mathrm{I}, \mathrm{P}\}, 100 \% \mathrm{BC}$ & $(11)$ & 11.32 \\
\hline Time-varying D, $50 \% \mathrm{BC}$, constant growth in $\{\mathrm{I}, \mathrm{P}\}$ & & -0.75 \\
\hline Time-varying D and growth in $\{\mathrm{I}, \mathrm{P}\}, 50 \% \mathrm{BC}$ & & -1.62 \\
\hline
\end{tabular}

\section{Possible Model Extensions}

Our analyses so far are based on an extremely simple economic model. However, our simple model can be further enriched. In this section, we discuss some possible extensions and the likely effects of such extensions on our results.

Endogenous Timing of Home Purchase. The optimal timing of home purchase $(t)$ in our model is exogenous and is calibrated using the average homebuyer's age (working years). If we can make this variable endogenous, the model has the potential to explain the difference in the optimal age of homebuyers across cohorts or regions. However, even if this variable is endogenized, we still need to calibrate the "deep 
parameters" in the model so that the model-predicted timing of home purchase matches that in the data. This is not much different from exogenously setting $t=15$ for a particular cohort as we did herein. Therefore, even if $t$ were endogenous, our results would still hold under similar calibrations.

Inclusion of Wealth Effects. In our simple model, a shelter is a pure consumption good and generates a constant lifetime utility unrelated to the consumption of other goods. In reality a shelter is also a capital good because it may yield capital gains when housing prices appreciate, which may generate positive wealth effects. However, this simplification does not hurt our analysis. If shelters were introduced into our model as a capital good (or durable consumption good), the situation is the same for the would-be homebuyer cohorts when housing price increases. However, for the homeowners who already own a house, it implies that their wealth would increase, which would decrease their saving incentives and mitigate the positive impact of rising housing prices on lifetime savings. Such a wealth effect may explain why the aggregate household saving rate in developed countries has been declining over the past decade. For example, Case, Quigley, and Shiller's (2006) empirical analysis based on U.S. cross-country and cross-state data finds that for every $10 \%$ increase in housing prices, the consumption-to-income ratio increases by $1.1 \%$ and the saving rate decreases by $1.1 \%$. These authors explain their findings based on the wealth effect. Hence, introducing a wealth effect into our model would only strengthen our conclusion that rising housing prices cannot explain China's high aggregate saving rate.

Depreciation Less than 100\%. The previous analyses are based on the assumption that a house has zero market value at the end of a homeowner's life. This assumption is not realistic, but it is an innocuous assumption and does not affect our main results. The reason is simple: If homeowners could sell their houses at the end of their lifetimes, they could then borrow against their home equity to increase consumption when young and use the proceeds from mortgage sales to repay their debt at the end of life. This would effectively relax borrowing constraints and reduce each individual's saving rate before buying a house. More specifically, suppose the 
market value of the house does not change over time and can be collateralized, an individual would then have no need to save before purchasing a home, and would incur a negative saving rate (or positive borrowing) equivalent to the market value of the house when purchasing a home, and incur a positive saving rate when selling the home at the end of life. Thus, the average lifetime saving rate would still be zero.

The Hump-Shaped Curve of Lifetime Income. Our model assumes that household income is either constant or continuously increasing over time. In reality, income follows a life cycle with an inverted-U shape: Personal income peaks in middle age. However, our results are not sensitive to this income pattern. The most important concern for a hump-shaped income profile is that agents are more borrowing constrained at a young age. In our model we have set the optimal age of home purchase at 35 (i.e., 15 years after birth or starting to work), which is roughly the peak year of lifetime income. Thus, our calibration makes the concern of borrowing constraints due to a hump-shaped income pattern less relevant. In addition, our calibration of the down-payment requirement of $50 \%$ has effectively overestimated the actual degree of borrowing constraints; we showed that even under a $50 \%$ down-payment requirement the influence of rising housing prices on the aggregate saving rate is insignificant. Hence, taking into account the inverted-U curve of lifetime income should not change our results significantly.

Bequests. In China, many parents give money to their children to buy houses because the children cannot afford the high mortgage costs. Hence, a popular view is that this type of altruism raised China's aggregate saving rate. We can use a version of our simple model to show that this view is incorrect because it again suffers from the fallacy of aggregation. The intuition is simple: Bequests from parents reduce their children's need to save; hence, at the aggregate level, bequests have little effect on the average household saving rate. In particular, under borrowing constraints, bequests can even reduce the positive impact of housing prices on the aggregate saving rate when both income and housing prices are increasing over time since they help relax the borrowing constraints of children. Suppose each generation receives a bequest at birth from their parents and leaves an identical amount of bequest at death to their 
children. This chain of overlapping-generation bequests effectively allows a consumer to borrow against future income because bequests resemble lump-sum subsidies when young and lump-sum taxes when old. Hence, bequests effectively reduce the borrowing constraints of each generation, and rapidly increasing housing prices will thus have less effect on the aggregate saving rate in an economy with bequests than one without bequests.

Endogenous Housing Supply and Demand. A typical life-cycle model with optimizing agents would treat housing supply and demand as endogenous. We avoid such an approach in this paper not only because it complicates the computations tremendously when housing prices and permanent income processes are all time varying (plus borrowing constraints and demographic changes), but most importantly such considerations would have only second-order effects on our results.

First, the most important effect of an endogenous housing supply by homebuilders or construction companies is on housing prices. Very few empirical studies exist to provide information to calibrate the housing supply elasticity and homebuilding technologies in China. Ultimately, the elasticity of housing supply and homebuilders' production technology in the model must be calibrated so that the model-generated housing price movements match those in the data. This is a daunting task for anyone familiar with the calibration literature. Our approach cleverly circumvents this difficulty because we can model any possible housing price movements in conducting our simulation analyses. Thus, we consider our choice of an exogenous housing supply a virtue rather than a weakness.

Second, if housing demand is endogenous rather than inelastic, the only consequence is that households in our model may opt to rent rather than purchase a home when housing prices are too high. This implies that the need to save is reduced and our results are thus enhanced rather than weakened.

\section{Transitional Dynamics after the Housing Reform}

The previous analyses focused on the equilibrium steady state, in which every generation is able to make housing purchases at a certain age. However, China did not 
start economic reform until 1978 and the housing reforms (that privatized the housing stock) started much later. Before the housing reform, urban people lived in government-provided public apartments and there was no need to save (and it was impossible) to buy a house. Since the reform, people must purchase their own houses and hence must save for such a purpose. However, if the saving rate was zero before the reform (this assumption is not realistic and goes against our results, so we can use it to conduct a robustness analysis), the expenditure-saving cancellation effect discussed previously may not take place immediately in the year of the reform. This implies a transitional period in which the aggregate saving rate may increase sharply initially after the housing reform and then return to the steady state level after people begin to purchase houses. Can such transitional dynamics explain China's persistently high aggregate household saving rate shown in Figure 1 ?

This section addresses this question. First, we briefly review China's housing reforms as an introduction to the background of our transitional-dynamic analysis in this section. Second, we simulate our model to see how aggregate household saving rate changes under the reform.

\subsection{China's Housing Reforms ${ }^{21}$}

In the planned economy era (from 1950 to 1978), all houses (apartments) were provided by the government essentially for free. This situation has changed gradually since 1978. In particular, from 1982 to 1985, more than 1,600 cities in China launched pilot projects of housing reforms. Most projects focused on privatizing public apartments. However, because of delays in wage reforms and the lack of a financial system to provide loans, the first-round housing reform failed.

In 1991, the city of Shanghai developed a system of publicly pooled funds for housing finance. This experiment was later introduced to the entire country between 1994 and 1997. These publicly pooled funds provided loans to enterprises and public institutions to build private housing units and to individuals to purchase houses, which was also the only channel for individuals to obtain loans in those days. During this

${ }^{21}$ This review is based on Chapter 13 of Deng and Liu (2009). 
period, about $20 \%$ to $30 \%$ of the housing stock was traded in the market, but most housing units were still provided by the government at subsidized rates.

Things changed dramatically in 1998, when China's State Council issued its "Directive on the Further Deepening of Urban Housing Reform and Accelerating Housing Construction". ${ }^{22}$ Since then, the provision of public housing ended nationwide and bank mortgage loans became available in addition to publicly pooled funds. Consequently, China entered an era of housing market boom.

\subsection{Transitional Dynamics}

Imagine an economy where housing is provided for free at the beginning years and households do not need to save. At some point in time, housing policy reform takes place and all generations born after that date must buy a house in the market using their own savings. Suppose the economy starts in 1988 and will last for 60 years (1988-2048)—-long enough to reach a steady state after the housing reform. Each generation lives for $T$ years, so there are $T$ generations alive at any time point. For generations born before 1998 (the year when the nationwide housing reform starts), they receive free housing from the government. For generations born after 1998, they must save for $t<T$ years to buy houses. The rest of the setting is the same as in our benchmark model (i.e., people start working in period 1 until retirement and need to save for 15 years to buy a house, and so on). For simplicity, we assume $a=0.1$ and $b=0.1$, so the permanent income and housing prices have an identical and constant

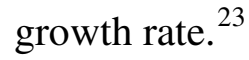

We consider the scenario of a $50 \%$ down-payment requirement. Notice that for generations born after 1998, their saving behaviors are identical to those in our benchmark model. Hence, the expenditures, savings, and the saving rate of each individual and age cohort are identical to our previous analyses in Table 6.

Since all generations born before 1998 can receive public housing for free, the aggregate saving rate is 0 before 1998 . We can use this piece of information and that

\footnotetext{
22 The Chinese title is 《关于进一步深化城镇住房制度改革加快住房建设的通知》。

${ }^{23}$ This assumption will raise the predicted steady-state saving rate from $4 \%$ to slightly above $5 \%$ because here the assumed growth rate of housing prices is higher than in the data and the assumed growth rate of income is lower than in the data.
} 
provided in Table 6 to compute the aggregate saving rate between 1988 and 2048. The resulting time series of the aggregate saving rate is shown in Figure 5.

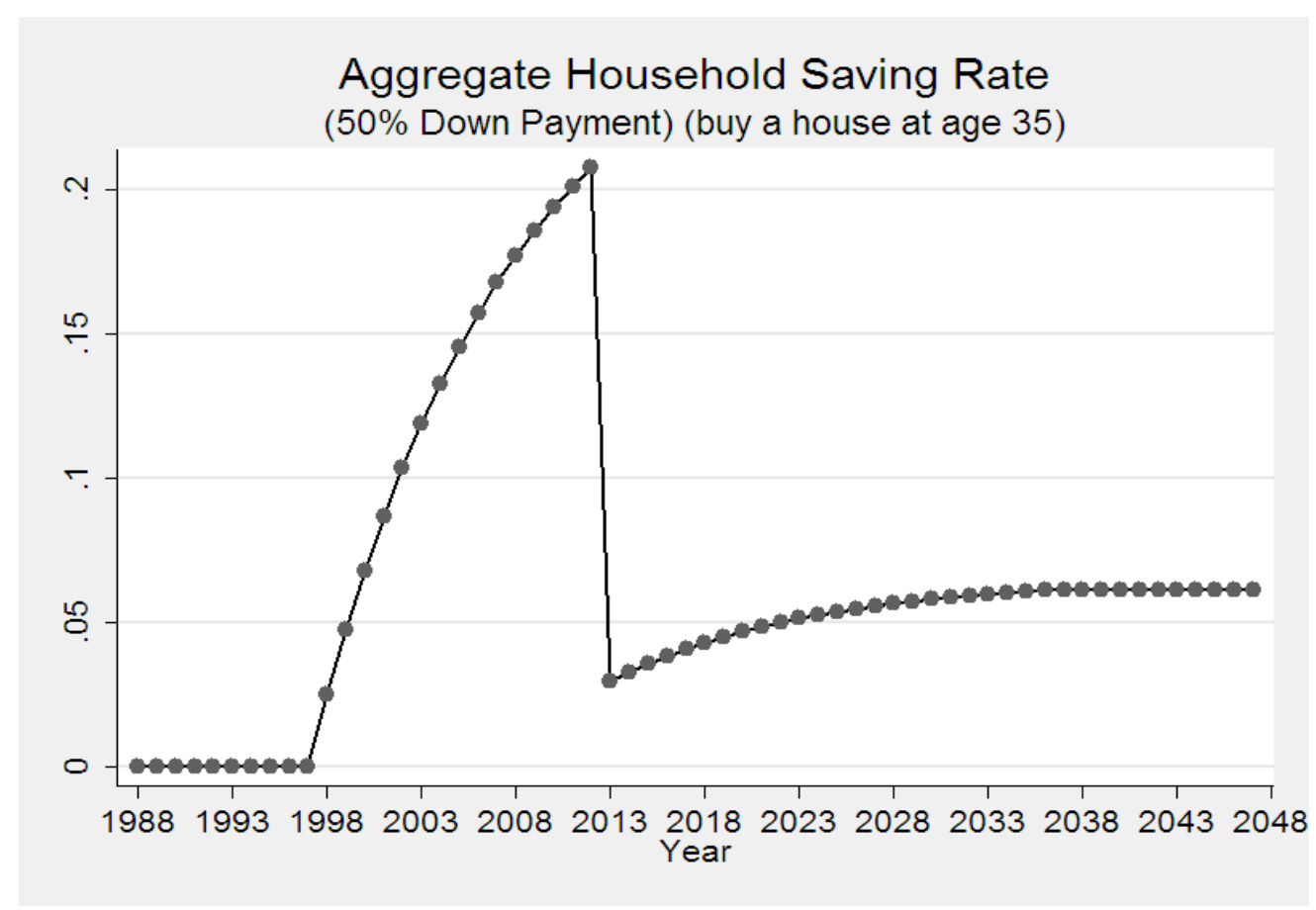

Figure 5. Transitional Dynamics

The figure shows that the aggregate saving rate remains zero between 1988 and 1998 and starts to increase in 1998 (the first year of housing reform) until 2013 (15 years later). During this period, an increasing number of newborn generations enter the pool of saving cohorts, driving up the aggregate saving rate. Because each would-be homebuyer generation needs to save for 15 years to afford a house, the first generation born (or started working) after 1998 will begin spending their savings in year 2013. This first wave of housing expenditures in 2013 will be so large relative to the entire societal savings of the would-be homebuyers that the aggregate saving rate will drop sharply and overshoot the steady state, because in 2013 there still exist older generations born before 1998 who do not need to save (called non-savers). After 2013, however, there number of non-savers diminishes in the economy so the aggregate saving rate will gradually move back toward the steady state after 2013.

In Figure 5, the predicted decline in the aggregate saving rate in 2013 is so sharp because we assume that everyone buys a house 15 years after birth. However, 15 is 
only the average number of years of saving needed to buy a house in China, but the actual distribution of homebuyers' age may be dispersed in the data. To capture this information in our simulation, we can assume that the age of becoming a homeowner is uniformly distributed between 11 to 20 years after birth, which means that in each generation cohort, one tenth of the population buys houses after saving for 11 years, one tenth after 12 years, and so on. The longest period of saving is 20 years.

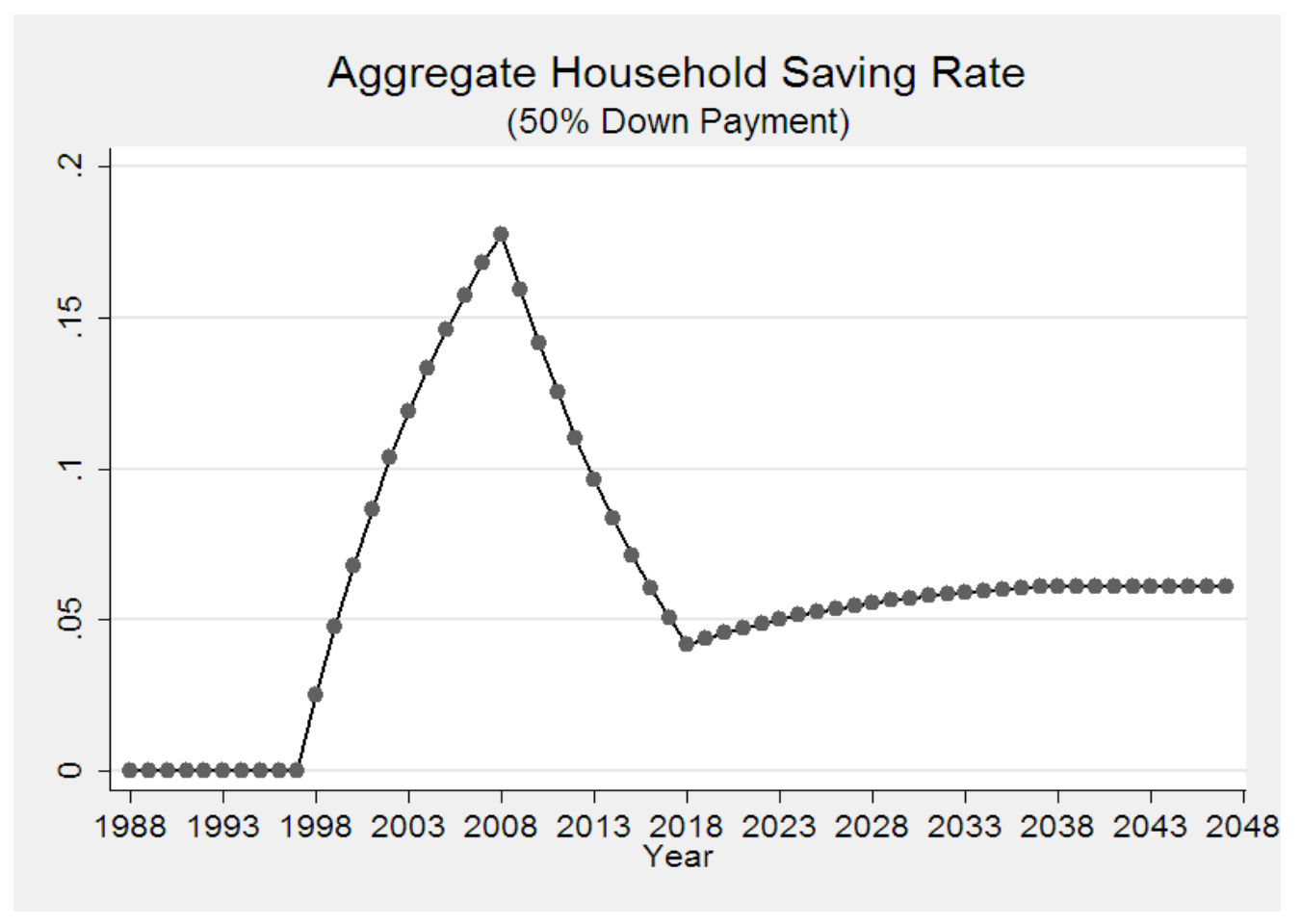

Figure 6. Transitional Dynamics (with a uniform age distribution)

Figure 6 shows the transitional dynamics of the aggregate saving rate when we take the age distribution of homebuyers into account. In the figure, the aggregate household saving rate peaked at 10 years after the reform (in 2008) and returns to the steady state more gradually and less sharply than in Figure 5. Comparing Figure 5 (or Figure 6) with Figure 1 indicates that the predicted transitional dynamics caused by the housing reform do not match the data. The data show (i) a persistently rising aggregate saving rate before 1994 with a peak of $28 \%$ in 1994 (3 years before the housing reform), (ii) a decline of the saving rate after 1995 with a trough of $13.5 \%$ in 2000 (2 years after the housing reform), and (iii) another round of rising saving rates 
since 2000. But the model predicts that the aggregate saving rate will start increasing rapidly in 1998 and reach a peak only after 2008 or 2013.

Even if the nationwide housing reform were perfectly anticipated before 1998, the transitional dynamics still would not explain the data. The key factor to explain is the sharp decline in China's saving rate from 1995 to 2000, but the nationwide housing reform started in 1998. For example, suppose that the 1998 housing reform was anticipated earlier (say in 1985), Figure 5 suggests that the aggregate saving rate would increase for 15 years until 2000 and then decline sharply. However, in the data the saving rate declined in 1995 until 2000. Alternatively, even if we shorten the minimum number of years required for saving from 15 to 10 years (as in Figure ), the predicted aggregate saving rate would still increase until 1998 and then sharply decline that year-since the majority of people would not be able to purchase houses in the market before 1998 but could start purchasing homes in that year. This prediction is still inconsistent with the fact that China's saving rate started to decline in 1995 ( 3 years before the reform) and reached a trough in 2000.

Therefore, given that the Chinese aggregate household saving rate was already above 22\% in 1992 (e.g., due to precautionary saving motives and rapid income growth after the 1978 economic reform, as suggested by Modigniani and Cao, 2004; and Wen, 2009, 2011) and this level of saving generally was enough for mortgage down payments in 1998, the housing reform in 1998 should not have had a significant transitional dynamic impact on the aggregate household saving rate. In other words, our steady-state analysis in the previous sections should be quite accurate to the first order in describing China's household saving behaviors and there is no clear evidence of transitional dynamics that prevented the expenditure-saving-cancellation effect in the measured aggregate saving rate. The empirical relationship shown in Figure 3 also indicates no significant transitional dynamic effects of housing prices on the aggregate household saving rate across provinces in the 1999-2008 sample period.

Alternative measure of household saving rate. Besides our definition of the aggregate household saving rate, there exist other measures. The most commonly used one is based on the "Urban Household Survey Data". Chamon and Prasad 
(2010)'s empirical analysis is based on this micro data set. As a robustness check, we use this data set to calculate the average household saving rate, which is shown in Figure 7 against our first measure.

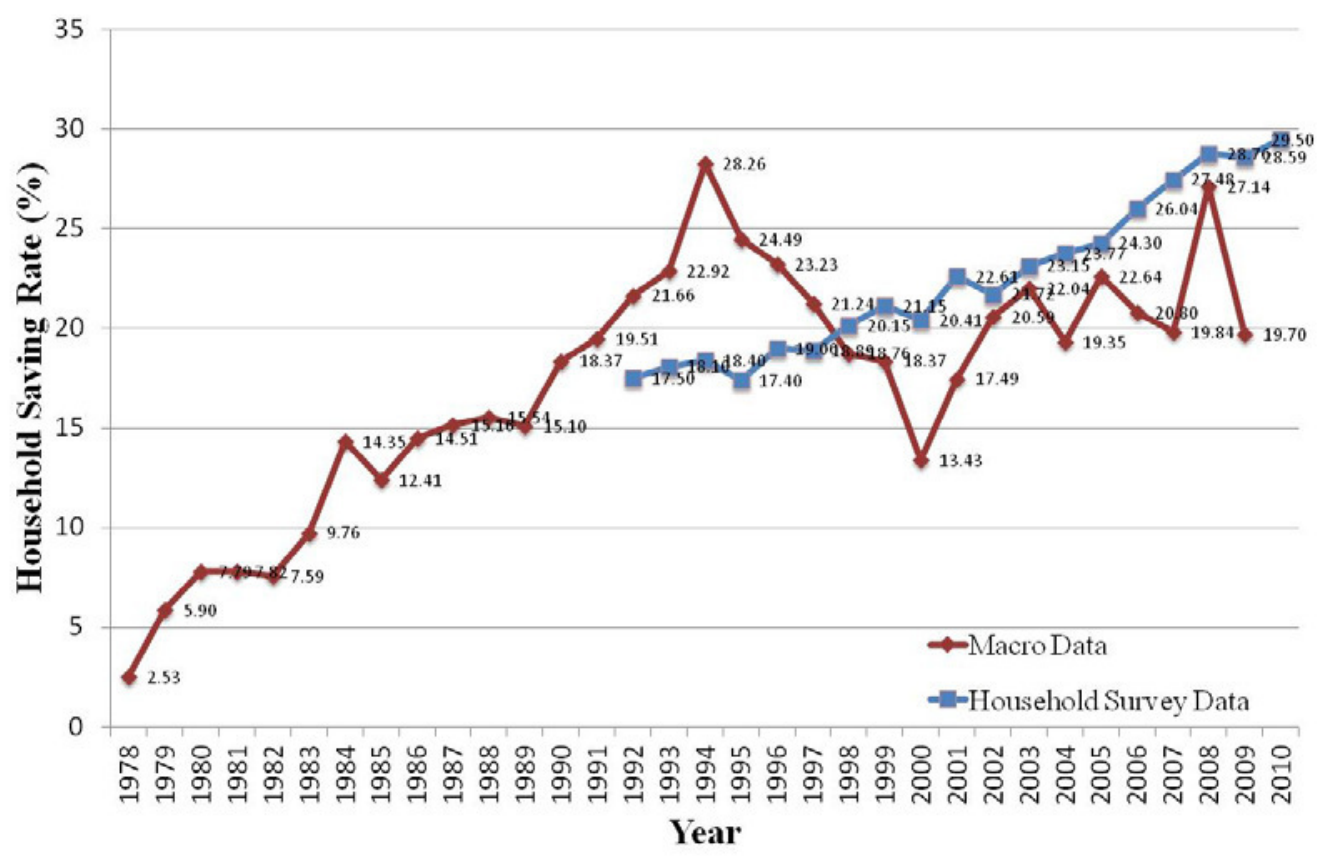

Figure 7. Chinese Household Saving Rate (Second Measure)

From Figure 7 we can see that this alternative measure of the household saving rate has very different dynamic patterns from our previous measure based on macro data - the second measure is much smoother. However, the magnitudes of both measures are broadly similar. Most importantly, this alternative measure of the household saving rate shows no transitional dynamic effect of the housing reform, as it is not matched at all by the pattern of the predicted transitional dynamics generated in the model.

\section{Conclusions}

Even when housing investment is excluded from the measured household saving rate, China's aggregate household saving rate of more than $25 \%$ is still one of the highest in the world. We investigate whether the rapidly rising housing prices (or other similar costs of living) in China can explain such a high saving rate. Common 
sense suggests that people must save more and for a longer period to purchase a home when housing prices increase. But empirical evidences show that the relationship between housing prices and the aggregate household saving rate is weak. The existing literature has not provided a good explanation for why this may be the case.

We show theoretically that (i) in a stationary economy, the aggregate household saving rate is independent of housing prices because of the expenditure-saving cancellation effects. (ii) In a nonstationary economy the measured aggregate saving rate can become quite sensitive to housing prices because of the population effects of changing housing prices, especially under borrowing constraints. However, with realistic degrees of borrowing constraints (such as allowing for a 50\% down payment or less) and anticipated income growth, rising housing prices can generate an additional aggregate saving rate of at most $4.3 \%$. This value becomes $1.6 \%$ if the down payment requirement is reduced to 40\%. (iii) Accounting for China's demographic features reduces the predicted aggregate saving rate further because the ratio of current homebuyers to future homebuyers has been increasing, which raises the population weights of the current homebuyers in the measured aggregate savings. Therefore, the implied saving rates become negative if the demographic structure is taken into account. (iv) If the transitional dynamics caused by housing reform in China are taken into account, such policy changes can potentially generate a substantial surge in the aggregate household saving rate but the timing of the surge would still be inconsistent with Chinese time-series data.

Therefore, our analysis provides a theoretical explanation for the weak empirical relationship between aggregate saving rates and housing prices in China and clarifies a popular misconception (or fallacy) that attributes the high aggregate household saving rate in China to the rapidly rising housing prices. This view ignores the saving-expenditure-cancellation effect across cohorts and the offsetting population effects from rising income and housing prices.

Our theory also explains the empirical findings of Chamon and Prasad (2010). Their empirical analyses show that the effects of homeownership status on the aggregate saving rate are not significant. They acknowledge that even if 
homeownership status can affect the aggregate saving rate, these channels can account for an increase in the saving rate only during an adjustment period and cannot themselves sustain high saving rates in the long run.

If the rapidly rising housing prices per se are not key for the persistently high aggregate Chinese saving rate, what factors actually cause such saving? We believe that large uninsurable risks (or idiosyncratic uncertainty in household income and spending needs) and borrowing constraints may provide the answer to China's high household saving rate. For example, Wen $(2009,2011)$ shows that when individuals face uninsured idiosyncratic risk (that does not diminish with income growth) and are borrowing constrained, their marginal propensity to save then becomes a positive function of the growth rate of their permanent income. Thus, rapid income growth could imply an extremely high household saving rate when financial markets are incomplete. In particular, Wen $(2009,2011)$ shows that a standard infinite-horizon growth model with incomplete financial markets could generate a near $30 \%$ aggregate household saving rate when household income growth rate is $10 \%$ per year. In this case, an individual's expenditure does not completely cancel his/her precautionary saving because of the need for a buffer stock at any moment in life. In other words, it is optimal to always maintain a large stock of personal saving proportional to wealth as self-insurance against unpredictable income or spending shocks (also see Chamon, Liu, and Prasad, 2011). ${ }^{24}$

Our findings also have important policy implications. Although rapidly rising housing prices themselves do not significantly contribute to the aggregate saving rate (at least not in the steady state), they may have severe adverse welfare consequences: (i) If housing wealth is not liquid or the transaction costs of reselling homes are high, then rising housing prices are similar to increasing income taxation on the young, which reduces consumption without increasing the utility value of a home. (ii) Even if mortgage wealth is perfectly liquid and can be converted to consumption goods at

\footnotetext{
${ }^{24}$ Wei and Zhang (2011) document a close relationship between sex ratio changes and the household saving rate in China. Our analysis suggests that rising marriage costs should have no consequence on the aggregate saving rate in the steady state. However, investigating the transitional dynamic effect of sex ratio changes on housing prices and the aggregate household saving rate would be an interesting future project that could be carried out using our simple model.
} 
zero costs, under borrowing constraints rising housing prices would force households to shift current consumption into the future, severely distorting consumption smoothing. Therefore, policies designed to reduce the growth rate of housing prices may not be effective in reducing the aggregate saving rate, but can nonetheless significantly improve welfare.

\section{Appendix for Figure 1}

We follow the methodology of Modigliani and Cao (2004) to calculate aggregate household saving rate. ${ }^{25}$ These authors obtain household consumption data from the tables of "Gross Domestic Product by Expenditure Approach" in China Statistical Yearbook and define household saving as changes in currency in circulation + total household (both urban and rural) deposits + bonds (new issues by the central government $)+$ individual investment in fixed assets. The disposable income is then defined as household consumption + household saving.

Based on this benchmark, we make several modifications in our calculation of the household saving rate (but our adjustment does not change the figure of Modigliani and Cao significantly). First, since this paper treats housing purchases as consumption instead of investment, we redefine household consumption expenditure as household consumption + total sales of housing (Table 1-14, China Compendium of Statistics 1949 2009).

Second, in our definition household saving also includes newly raised capital from A shares in the stock market (Table 19-18, China Statistic Yearbook 2010).

Third, Modigliani and Cao treat individual investment in fixed assets (sum of investment in fixed assets by private and self-employed companies) as household investment. We think it is more appropriate to treat this investment as corporate saving instead of household saving, so we exclude this part in our definition of household saving.

\footnotetext{
${ }^{25}$ Bai and Qian (2009) updated Modigliani and Cao (2004)'s household saving rate from 2000 to 2006, but they did not eventually use this data directly in their paper.
} 
Fourth, we treat consumption loan as negative saving. Modigliani and Cao do not consider this element because the scale of consumption loan is extremely small before 2000. However, China's consumption loan market has developed rapidly and significantly after 2000 . Therefore, we calculate the changes in consumption loan (including housing, car, education etc.) and deduct them from household saving.

To sum up, the method we used to calculate aggregate household saving rate is based on the following definitions: Aggregate Household Saving Rate $=$ Household Saving / Household Disposable Income. Household Saving = Changes in Currency and Deposit + New Issued Bonds + Raised Capital of A Shares - Change in Consumption Loans. Household Consumption $=$ Household Consumption (services plus nondurable goods and durable goods) + aggregate Sales of Housing. Household Disposable Income $=$ Household Saving + Household Consumption .

\section{Reference}

[1] Bai, C. and Z. Qian, 2009, "Who Is the Predator and Who Is the Prey-An Analysis of Changes in the State of China's National Income Distribution," Social Sciences in China, 4, 179-205. (In Chinese: 白重恩、钱震杰, “谁在挤占居民的收入一我国国民收入分配 格局变化的分析”, 《中国社会科学(英文版)》, 2009 年第 4 期, 第 179-205 页).

[2] Bernanke, B., 2005, "The Global Saving Glut and the U.S. Current Account Deficit", Remarks by Governor Ben S. Bernanke at the Sandridge Lecture, Virginia Association of Economics, Richmond, Virginia, March 10, 2005.

[3] Carroll, C. , J. Overland, and D. Weil, 2000, "Saving and Growth with Habit Formation", American Economic Review 90(3), 341-355.

[4] Case, K., J. Quigley, and R. Shiller, 2006, "Comparing Wealth Effects: The Stock Market versus the Housing Market”, Advances in Macroeconomics 5, 1-31.

[5] Chamon, M. and E. Prasad, 2010, "Why are Saving Rates of Urban Households in China Rising”, American Economic Journal: Macroeconomics 2(1), 93-130.

[6] Chamon, M., K. Liu, and E. Prasad, 2011, "Income Uncertainty and Household Savings in China", NBER and IZA Discussion Paper No. 5331.

[7] Chen, K., A. Imrohoroglu, and S. Imrohoroglu, 2006, "The Japanese Saving Rate", The American Economic Review 96, 1850-1858.

[8] Deng, D., C. Liu, 2009, “Thirty Years' Reform and Opening up—China’s Social Security 
System Reform, Review, Evaluation and Prospect”, Beijing, China Social Science Press. (In Chinese: 邓大松、刘昌平等, “改革开放 30 年一中国社会保障制度改革回顾、评 估与展望”,北京,中国社会科学出版社,2009 年.)

[9] Friedman, M., 1957, “A Theory of the Consumption Function”, Princeton University Press.

[10] Hayashi, F., 1986, "Why Is Japan's Saving Rate So Apparently High?”, NBER Macroeconomics Annual 1, 147-210.

[11] He, X. and Y. Cao, 2007, "Understanding the High Saving Rate in China", China and World Economy 15, 1-13.

[12] Horioka, C. Y. 1990, "Why Is Japan's Household Saving Rate So High? A Literature Survey", Journal of The Japanese and International Economics, Vol. 4, 49-92.

[13] Horioka, C. Y. and J. Wan, 2007, "The Determinants of Household Saving in China: A Dynamic Panel Analysis of Provincial Data", Journal of Money, Credit and Banking, Vol.39, Issue 8, 2077-2096.

[14] Modigliani, F. and S. Cao, 2004, "The Chinese Saving Puzzle and the Life-Cycle Hypothesis", Journal of Economic Literature 42, 145-170.

[15] Song, Z. and D. T. Yang, 2010, "Life Cycle Earnings and Saving in a Fast-Growing Economy", Chinese University of Hong Kong Working Paper.

[16] Wei, S.J. and X. Zhang, 2011, "The Competitive Saving Motive: Evidence from Rising Sex Ratios and Savings Rates in China", Journal of Political Economy (forthcoming).

[17] Wen, Y., 2009, "Saving and Growth under Borrowing Constraints: Explaining the 'High Saving Rate' Puzzle”, Federal Reserve Bank of St. Louis Working Paper 2009-045C.

[18] Wen, Y., 2011, “Explaining China's Trade Imbalance Puzzle”, Federal Reserve Bank of St. Louis Working Paper 2011-018A.

[19] Yuan, Z. and Z. Song, 1999, "Urban consumption behavior and China's economic growth”, Economic Research 11, 20-28 (In Chinese: 袁志刚、宋铮, “城镇居民消费行为 变异与我国经济增长”, 《经济研究》,1999 年第 11 期,第 20-28 页).

[20] Yuan, Z. and Z. Song, 2000, "Demographic structure, pension system, and optimal saving rate”, Economic Research 11, 24-32 (In Chinese: 袁志刚、宋铮,“人口年龄结构、养老 保险制度与最优储蓄率”, 《经济研究》,2000 年第 11 期,第 24-32 页). 